\title{
HYDROGRAPHS OF LAKE STAGE, STREAM DISCHARGE, AND HYDRAULIC HEAD IN GROUND WATER FOR THE MIRROR LAKE AREA, NEW HAMPSHIRE, 1979-1995
}

by T.C. Winter ${ }^{1}$, D.C. Buso ${ }^{2}$, R.S. Parkhurst ${ }^{1}$, D.O. Rosenberry ${ }^{1}$, and M. L. Martinez ${ }^{1}$

1 U.S. Geological Survey, Lakewood, Colorado

2 Institute of Ecosystem Studies, Millbrook, New York

\section{U.S. GEOLOGICAL SURVEY}

Open-File Report 99-239

Denver, Colorado

1999 


\section{U.S. DEPARTMENT OF THE INTERIOR \\ BRUCE BABBIT, Secretary}

\section{U.S. GEOLOGICAL SURVEY}

Charles G. Groat, Director

The use of firm, trade, and brand names in this report is for identification purposes only and does not constitute endorsement by the U.S. Geological Survey.

For additional information write to:

Chief, Branch of Regional Research U.S. Geological Survey Box 25046, MS 418 Denver Federal Center Denver, CO 80225
Copies of this report can be purchased from:

U.S. Geological Survey Information Services

Box 25286

Denver Federal Center Denver, CO 80225 


\title{
HYDROGRAPHS OF LAKE STAGE, STREAM DISCHARGE, AND HYDRAULIC HEAD IN GROUND WATER FOR THE MIRROR LAKE AREA, NEW HAMPSHIRE, 1979-1995
}

\author{
by T.C. Winter ${ }^{1}$, D.C. Buso ${ }^{2}$, R.S. Parkhurst ${ }^{1}$, D.O. Rosenberry ${ }^{1}$, and M. L. Martinez ${ }^{1}$ \\ ${ }^{1}$ U.S. Geological Survey, Lakewood, Colorado \\ ${ }^{2}$ Institute of Ecosystem Studies, Millbrook, New York
}

\section{INTRODUCTION}

Mirror Lake has been the focus of limnological studies since the mid 1960s (Likens, 1985). Although some hydrological work was done in support of the earlier studies, extensive hydrologic instrumentation of the lake and its watershed (Figure 1) was initiated in 1979 to focus research on the interaction of the lake with atmospheric water, surface water, and ground water (Winter, 1984).

The purpose of this report is to present the basic data on lake stage, stream discharge to and from the lake, and hydraulic head in ground water in the Mirror Lake watershed from 1979 through 1995. Data from all installations and gages do not cover this entire time period. The longest records are of hydraulic head in ground water in those water-table wells and piezometers that were drilled in 1979. Continuous records of stream discharge began in 1981. The data are presented in graphical form; specific data values can be obtained upon request.

\section{METHODS}

\section{Lake stage}

Lake stage was measured continuously using a float and strip-chart recorder placed in a stilling well attached to the outlet dam structure. The dam consists of wooden boards that fit into a steel and concrete structure.

\section{Surface discharge from Mirror Lake}

Prior to 1990 , surface discharge from the lake was measured by considering the top board of the dam as a broad-crested weir, and using lake-stage data in the weir formula. The calculated discharge was questionable at times because, (1) at some high lake stages water would flow around the dam and not be measured, (2) the condition of the boards varied, and (3) leakage between the boards was not measured continuously. To address this third problem, v-notch weirs were installed as part of the dam structure directly downstream of the boards as a means to measure the leakage between the boards. Staff gages in the weir pools were read weekly, and discharge from the weirs was estimated for the week. None of the surface-outflow data that had been calculated using the broadcrested weir method are shown in this report.

To increase the accuracy and to simplify measurement of surface discharge from the lake, a Parshall flume was constructed in 1990 in the stream channel about 10 meters downstream of the dam. Because the flume size was selected to measure medium to large flows from the lake, the lowest flows (largely seepage through the boards) could not be measured accurately. To overcome this problem, a portable weir was designed that could 
be attached to the flume at times of low flows. The weir was attached to the downstream end of the flume so the flume itself provided the pool behind the weir plate, and the flume's stilling well could be used to obtain stages to be used in the weir formula.

Because of the uncertainty of some of the surface-outflow data collected before the outlet flume was constructed, a statistical relationship between lake stage and discharge measured by the flume was determined. This relationship, which has three parts depending on the stage of the lake, was used to back-calculate surface discharge from the lake for 1981-1990. At times when the only surface discharge from the lake is leakage through the boards, the relationship is considered to be a constant. As a result, the lowest flows during 1981-1990 are shown as a straight line at about 0.8 liters per second (Figure 2). Beginning in 1991, the lowest flows were gaged using the portable weir attached to the flume, resulting in more accurate values.

\section{Stream discharge to Mirror Lake and stream discharge from the Mirror Lake Fen}

The three streams flowing into Mirror Lake and the stream flowing from Mirror Lake fen were gaged using Parshall flumes. All flumes were gaged continuously using floats and strip-chart recorders placed in a stilling well attached to the flume. The flumes were insulated and heated, resulting in continuous records through most winters.

\section{Hydraulic head in ground water near Mirror Lake}

Data on hydraulic head in ground water consist of two types, (1) the hydraulic head of the water table, which is the upper surface of the ground-water system, at different locations within the area, and (2) the hydraulic head at different depths within the groundwater system, as determined from piezometers completed at different depths at the same locality. All water-table wells, except wells 19, 20, and 21 , were constructed by (1) drilling a hole using a power or hand auger, (2) inserting a well screen attached to the bottom of casing, and (3) backfilling the space between the casing and drill-hole wall with drill cuttings. Wells 19,20 , and 21 were driven to a depth just below the water table. Piezometers within the glacial deposits were constructed by (1) drilling a hole using the mud-rotary method, (2) inserting a casing with a well screen attached to the bottom and a petal cement basket positioned where the screen is attached to the casing, (3) pumping cement into the annular space between the casing and drill-hole wall above the petal cement basket for a length of $8 \mathrm{~m}$ or to land surface. Most water-table wells and all piezometers completed in the glacial deposits consist of PVC, are $5.1 \mathrm{~cm}$ in diameter, and the screens are $61-\mathrm{cm}$ long. A few water-table wells consist of steel, are $3.2 \mathrm{~cm}$ in diameter, and the screens are $61-\mathrm{cm}$ long. Bedrock piezometers were constructed by (1) drilling a hole using the mud-rotary method to a depth of $3 \mathrm{~m}$ into the crystalline bedrock, (2) inserting a 16-cm diameter steel casing into the hole, and (3) cementing the steel casing in place to prevent transfer of water between the glacial deposits and bedrock along the annular space between the casing and drill-hole wall. The bedrock wells are open-hole below the bottom of the casing.

Water levels in the water-table wells and all piezometers, except those in piezometer nest K1 were measured weekly to biweekly using a calibrated steel tape or a calibrated electric tape. Piezometers at the K1 location (Figure 1) were instrumented in 1987 to obtain continuous data on hydraulic head at different depths within the ground-water system at a location downgradient from the lake. The instruments consisted of floats and potentiometers fixed to the float wheels. A signal was sent from the potentiometer to a digital data logger at 1-minute intervals. The data logger calculated average water level at 2hour and 24-hour intervals. All water-level data are referenced to altitude above mean sea level. 


\section{Presentation of data}

To facilitate comparison of hydrographs, the vertical scales of the discharge hydrographs for the three inlet streams and the outlet are the same. Similarly, the vertical scales of the ground-water hydrographs for most of the wells are the same; two meters. Ground-water levels that fluctuated much less than, or more than, two meters were plotted at scales that are multiples of 2 meters. For example: hydrographs of ground-water levels for (1) wells 19, 20, and 21 have a 1-m vertical scale; (2) wells 3, 3A, 4-14, 4-25, 16, 18, piezometer nests K1, K2, and K3 have a 4-m vertical scale; (3) piezometer nests FS1 and FSE have an 8-m vertical scale; and (4) piezometer nest TR has a $16-\mathrm{m}$ vertical scale.

At two localities, two wells positioned less than $2 \mathrm{~m}$ apart were constructed as described above for water-table wells. Hydrographs for these four wells are shown in Figure 11. In the upper panel of figure 11, the water table well is well $3 \mathrm{~A}$ and well 3 is completed about 4.3-m deeper. In the lower panel of figure 11, the water table at well is well 4-14 and well 4-25 is completed about $3.3 \mathrm{~m}$ deeper. The deeper wells at these two localities are considered to be poorly constructed piezometers because they were not constructed using the method described above for the other piezometers.

In the figures that show hydraulic head in the piezometers (Figures 12,13, and 14) the hydrograph labels indicate the depth of the bottom of the well screen in feet below land surface. Hydraulic head in bedrock is indicated by the hydrograph labeled BR. At the K1 site (Figure 12), the water-table well is labeled 8. At the FSE site (Figure 13), the watertable well is labeled WT. At the FS1 site (Figure 14), the water-table well is labeled 17. At the remainder of the piezometer nests, the shallowest piezometer is near the water table; therefore, water-table wells were not constructed at these sites.

\section{REFERENCES}

Likens, G.E., ed., 1985, An ecosystem approach to aquatic ecology: Mirror Lake and its environment: New York, Springer-Verlag, $516 \mathrm{p}$.

Winter, T.C., 1984, Geohydrologic setting of Mirror Lake, West Thornton, New Hampshire: U.S. Geological Survey Water-Resources Investigations, WRI-84-4266, $61 \mathrm{p}$. 
Figure 1 - Location of lake-stage gage, stream gages, water-table wells, and piezometer nests in the Mirror Lake area.

Figure 2 - Stage of Mirror Lake, discharge from Mirror Lake, and discharge from the Mirror Lake fen.

Figure 3 - Discharge of the three Mirror Lake inlet streams; Northwest, West, and East. $10-13$

Figure 4 - Hydraulic head of the water table at wells 2, 5, 6, and 7.

Figure 5 - Hydraulic head of the water table at wells $8,9,10$, and 11 .

Figure 6 - Hydraulic head of the water table at wells 12, 13, 14, and 15.

Figure 7 - Hydraulic head of the water table at wells 16, 18, 22, and 23.

Figure 8 - Hydraulic head of the water table at wells 19, 20, and 21.

Figure 9 - Hydraulic head of the water table at wells 24, 25, 26, and 28.

Figure 10 - Hydraulic head of the water table at wells $29,30,31$, and 32.

Figure 11 - Hydraulic head of the water table at well 3A and head 4.3-m deeper at that site in well 3; Hydraulic head of the water table at well 4-14 and head $3.3 \mathrm{~m}$ deeper at that site in well 4-25. Wells 3 and $4-25$ were constructed similar to the water-table wells, not as the piezometers where petal baskets and grout were used.

Figure 12 - Hydraulic head within the ground-water system at piezometer nests $42-45$ $\mathrm{K} 1$ and $\mathrm{K} 2$. Hydrograph labels indicate the depth of the bottom of the well screen in feet below land surface. The hydrograph labeled 8 represents the hydraulic head of the water table at piezometer nest K1. Head in bedrock is indicated by the hydrograph labeled BR.

Figure 13 - Hydraulic head within the ground-water system at piezometer nests K3 and FSE. Hydrograph labels indicate the depth of the bottom of the well screen in feet below land surface. Head of the water table at piezometer nest FSE is indicated by the hydrograph labeled WT. Head in bedrock is indicated by the hydrograph labeled BR for K3 and B1 for FSE. 46-49

Figure 14 - Hydraulic head within the ground-water system at piezometer nests TR and FS1. Hydrograph labels indicate the depth of the bottom of the well screen in feet below land surface. Well 17 is a water-table well at piezometer nest FS1. Head in bedrock is indicated by the hydrograph labeled BR. 


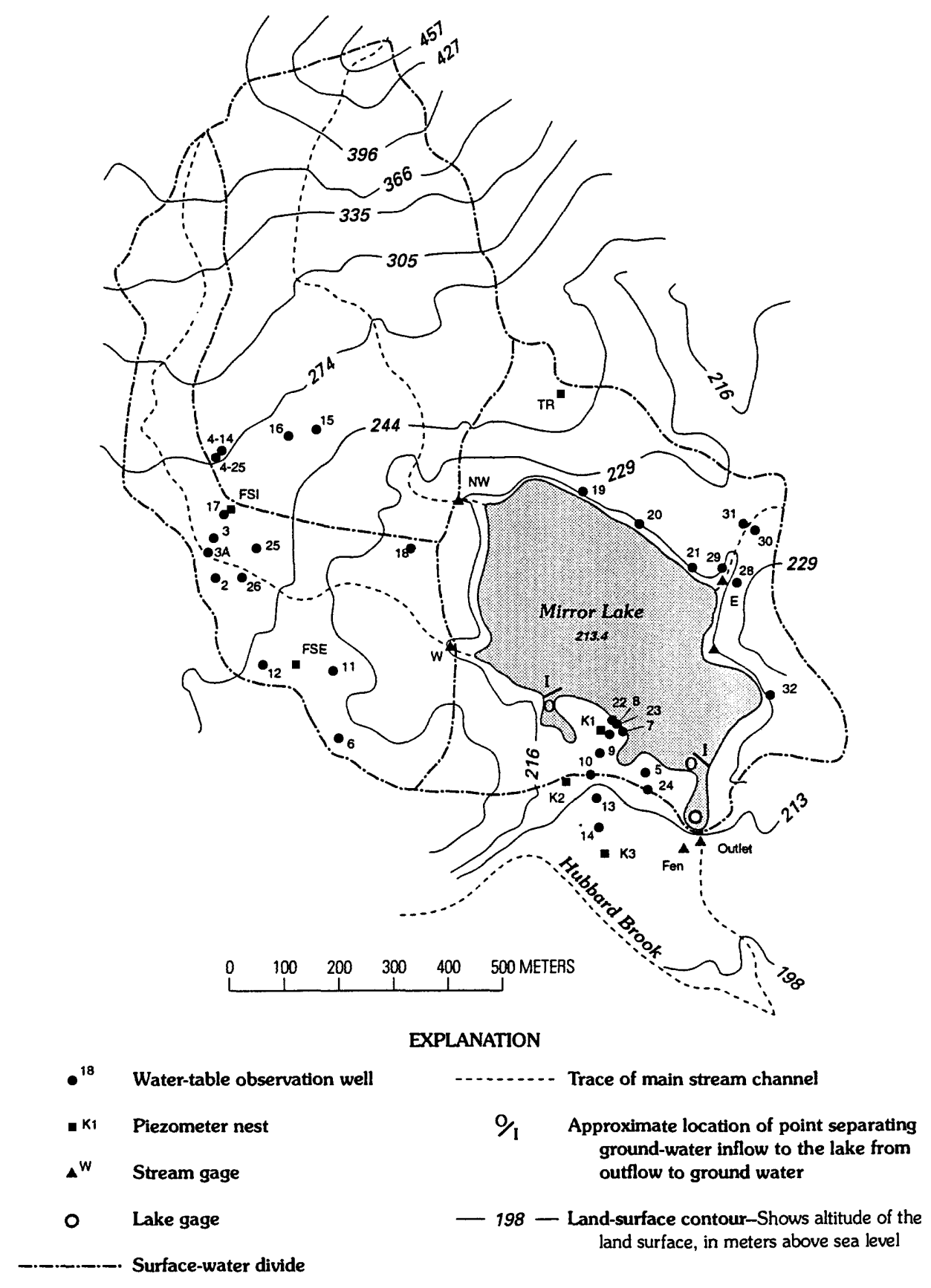

Figure 1. Location of lake-stage gage, stream gages, water-table wells, and piezometer nests in the Mirror Lake area. 

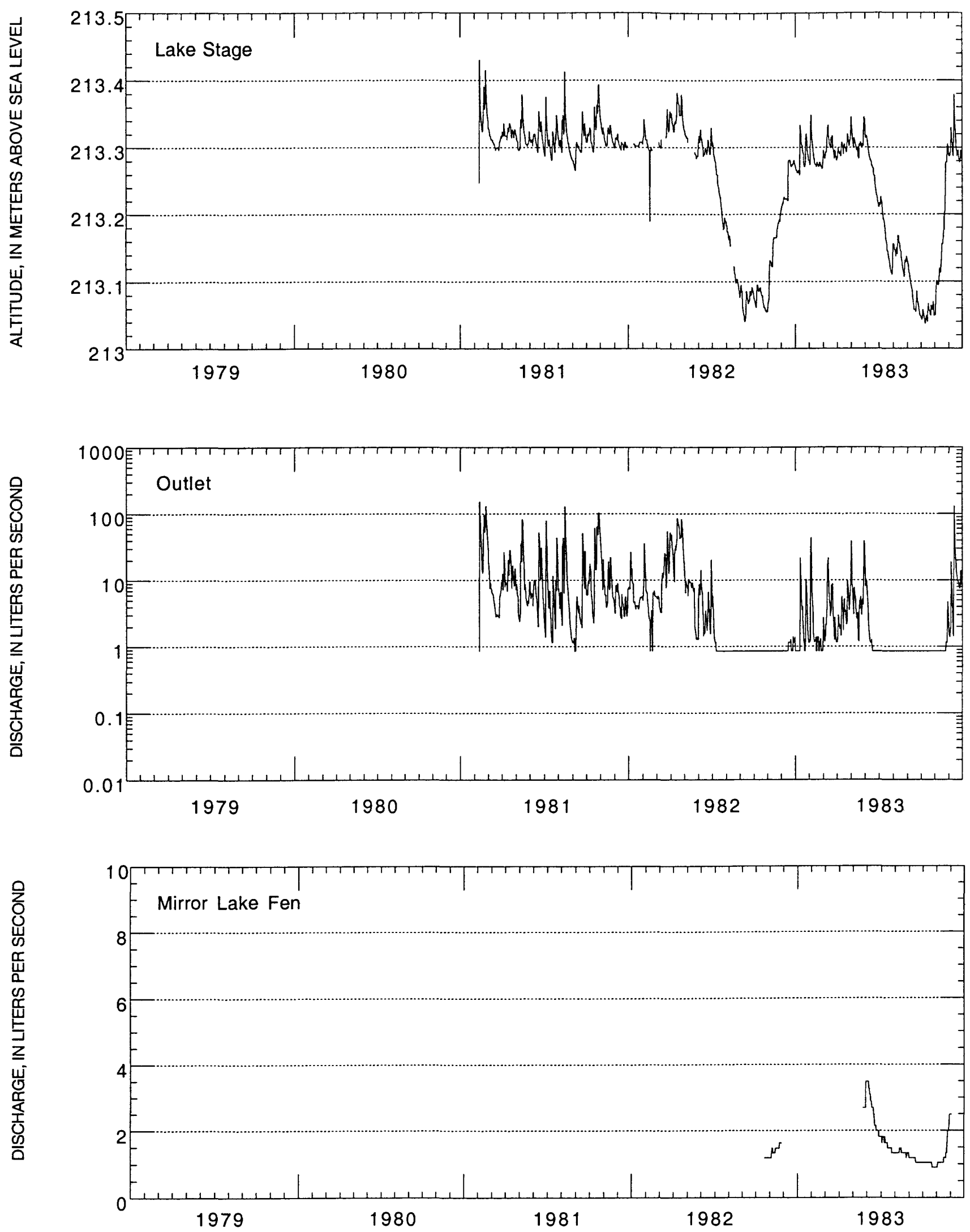

Figure 2. Stage of Mirror Lake, discharge from Mirror Lake, and discharge from the Mirror Lake fen. 


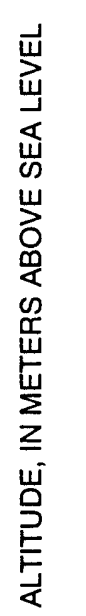

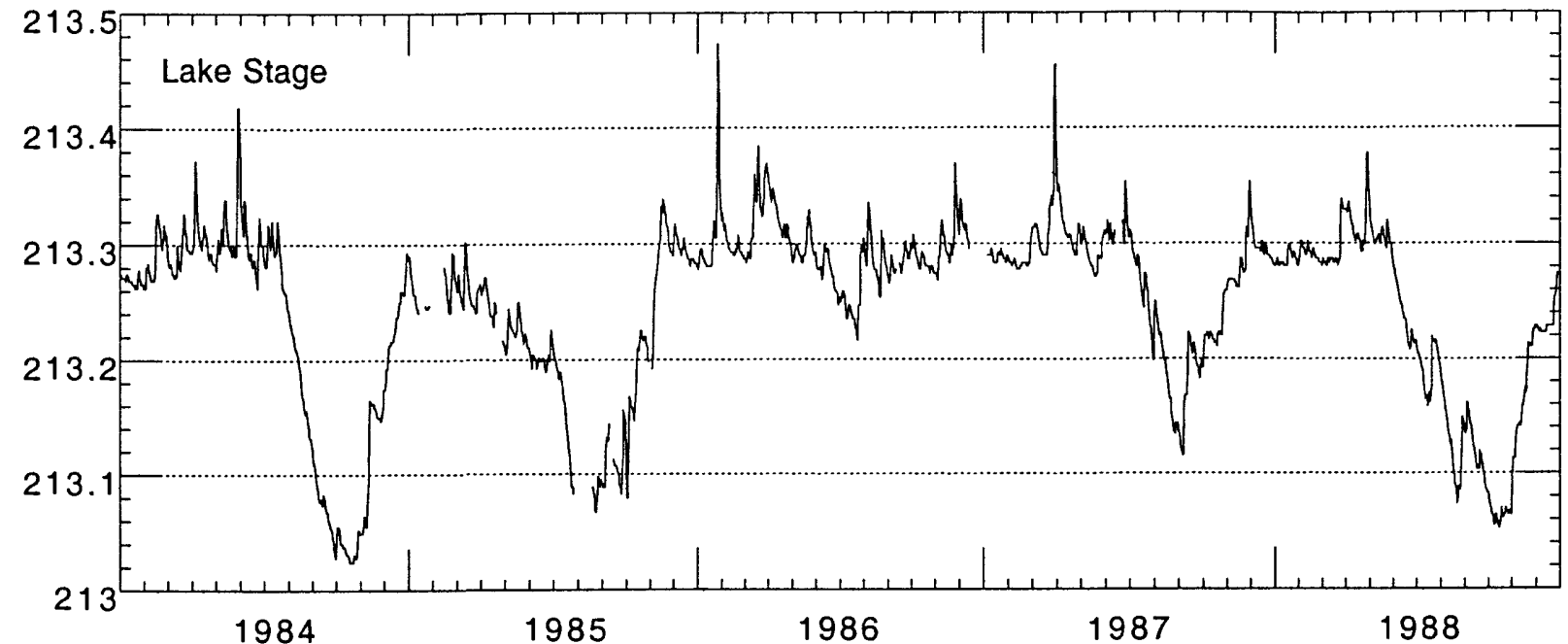

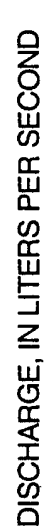

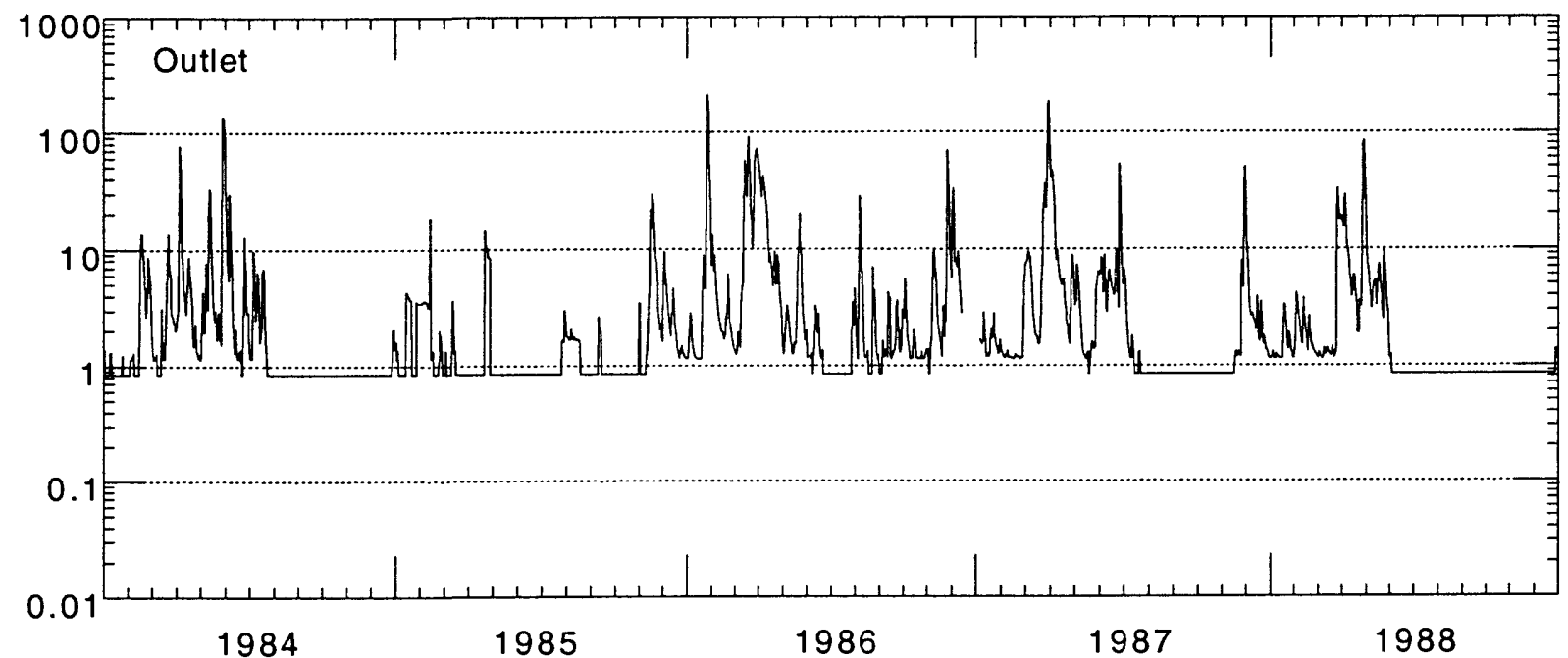

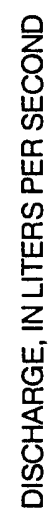

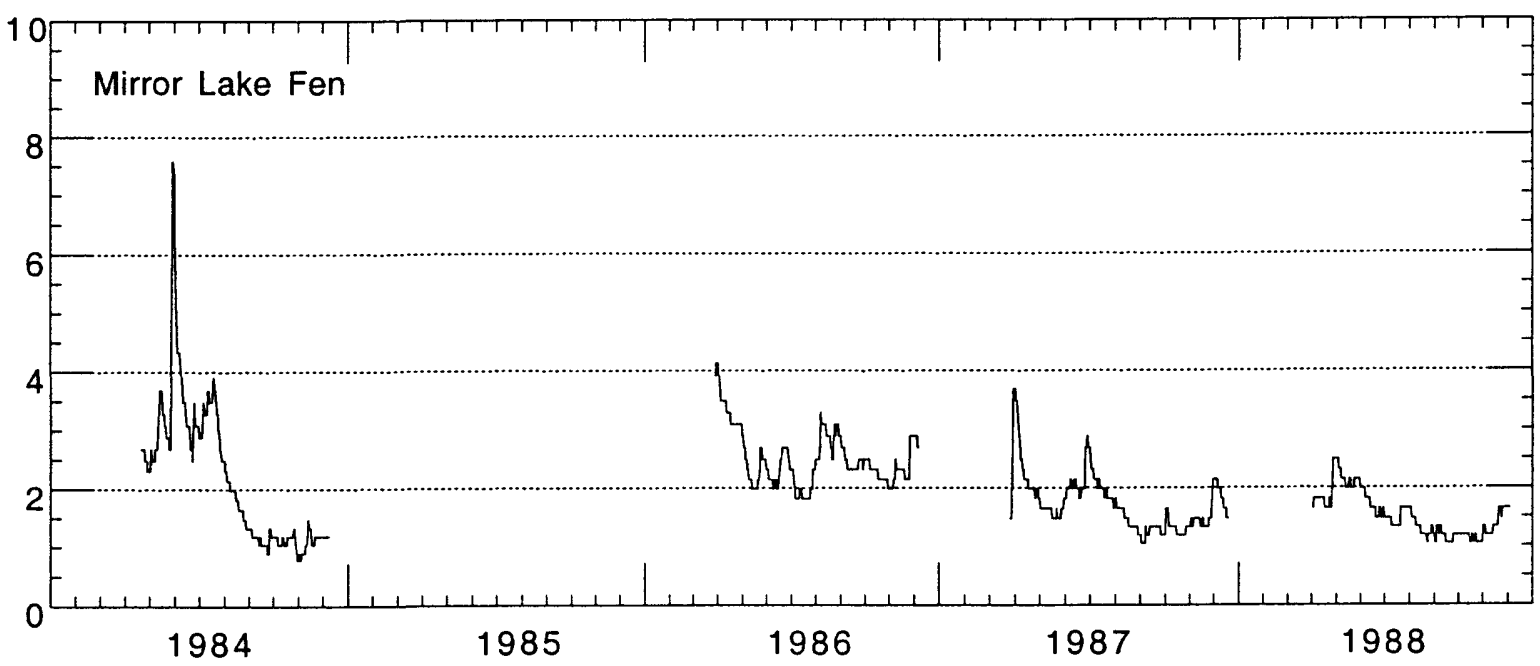



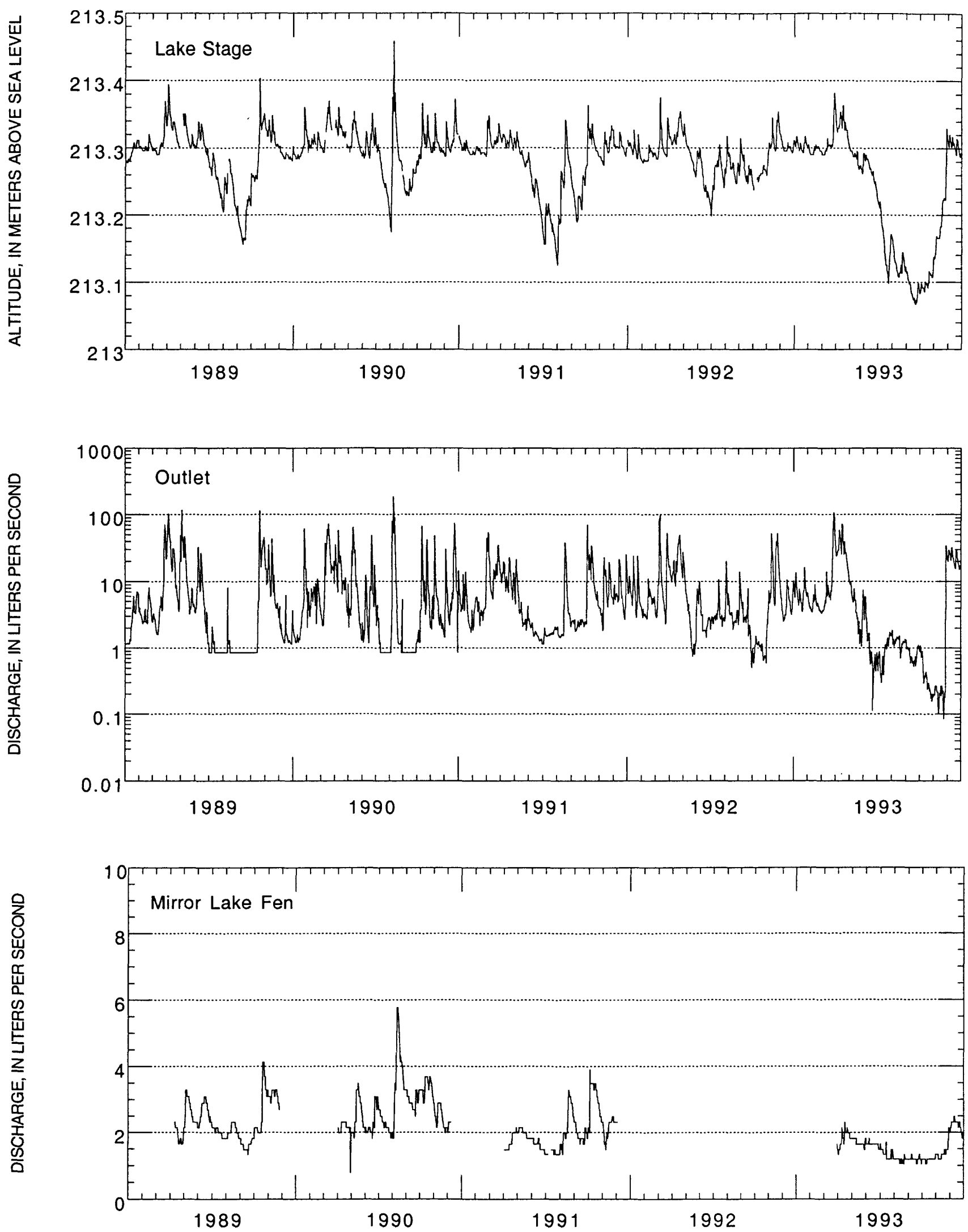

Figure 2. Stage of Mirror Lake, discharge from Mirror Lake, and discharge from the Mirror Lake fen. - Continued 

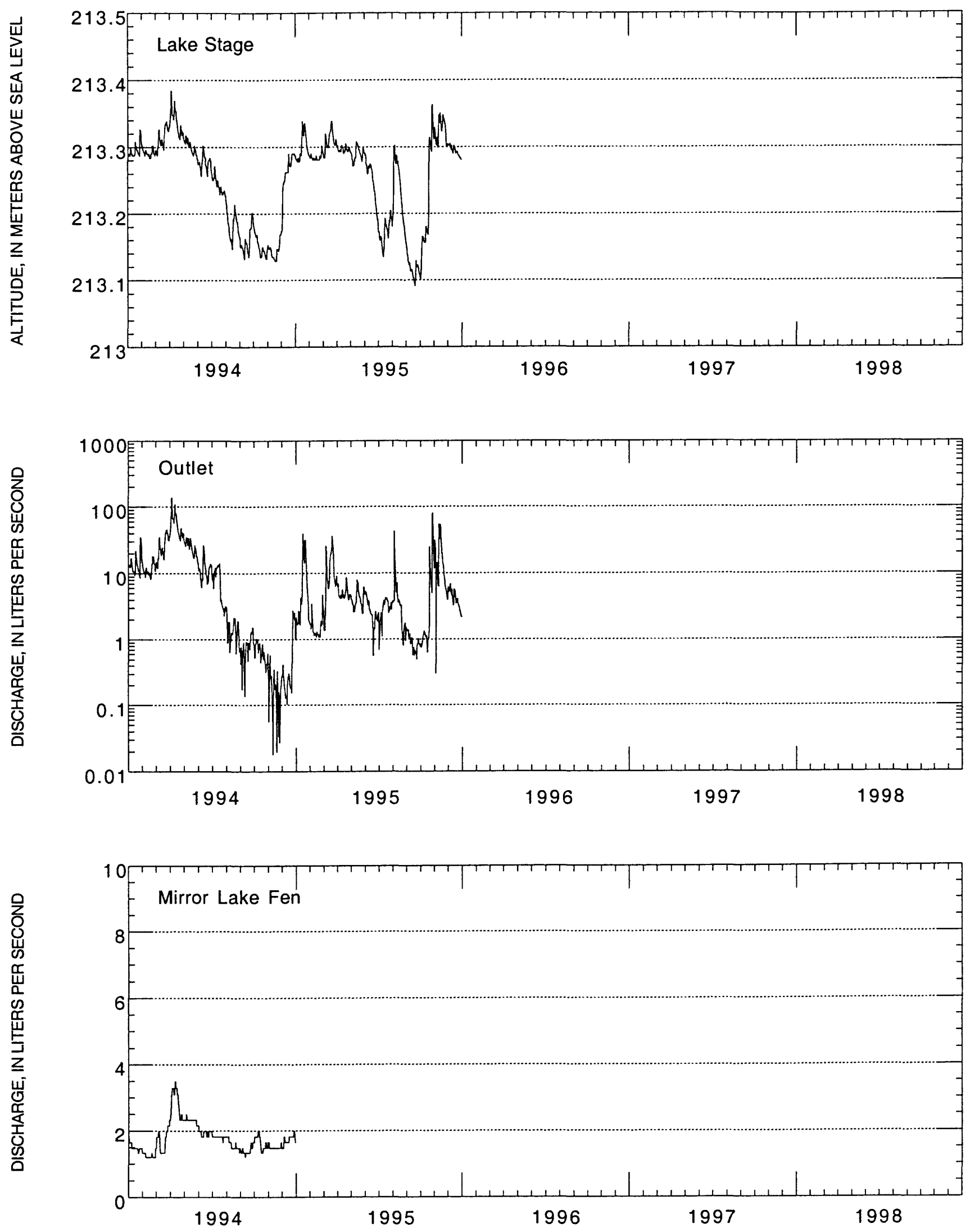

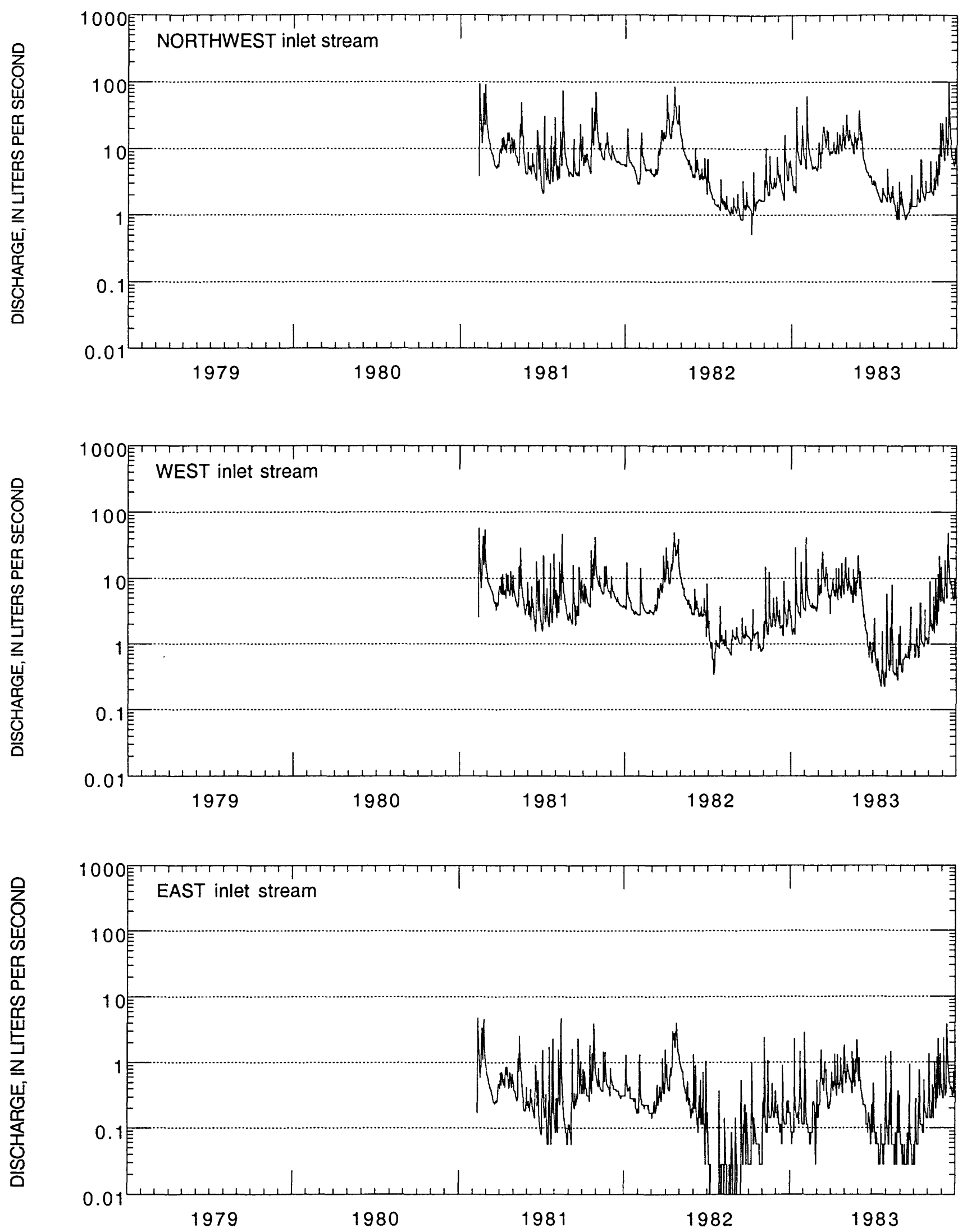

Figure 3. Discharge of the three Mirror Lake inlet streams; Northwest, West and East 

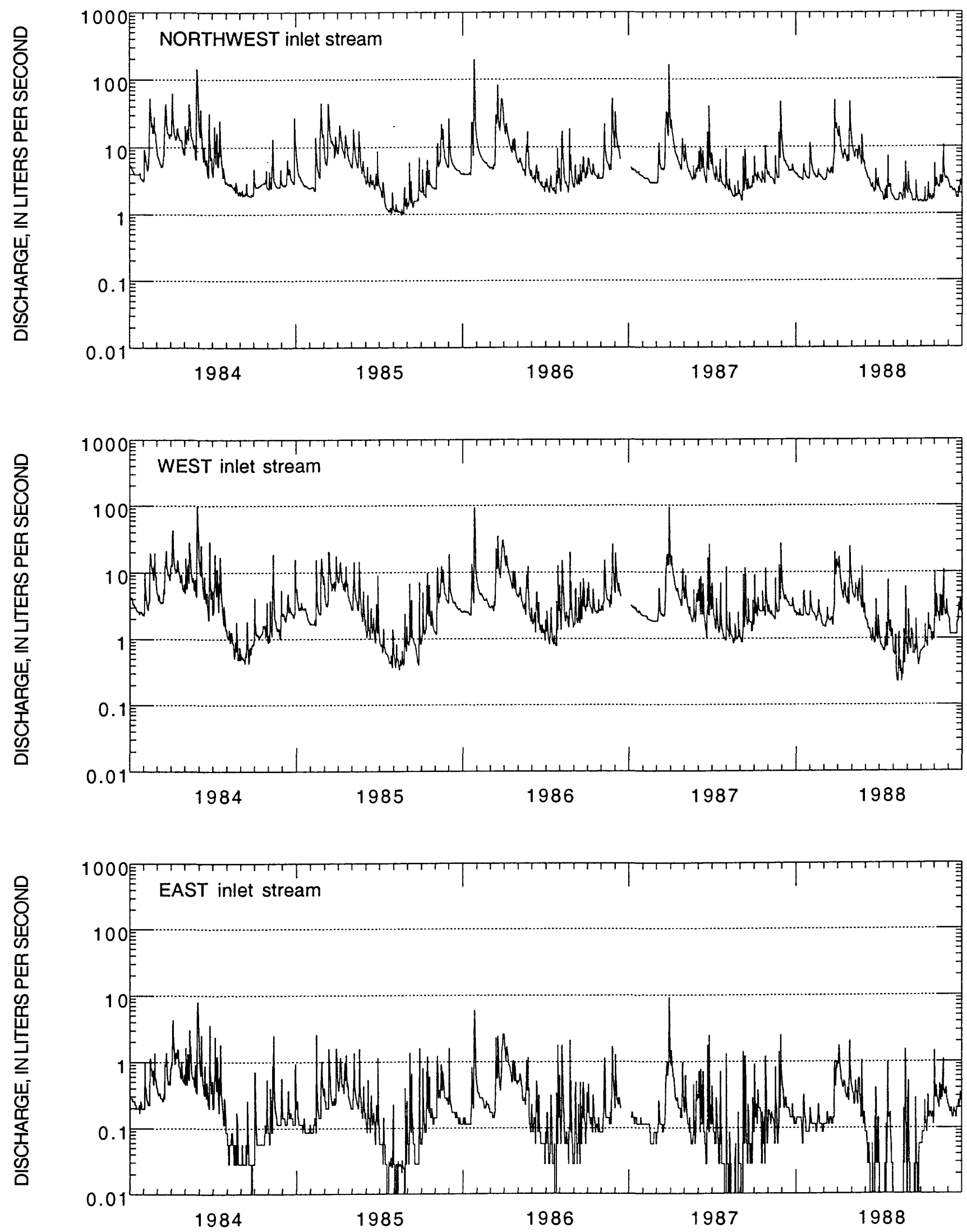

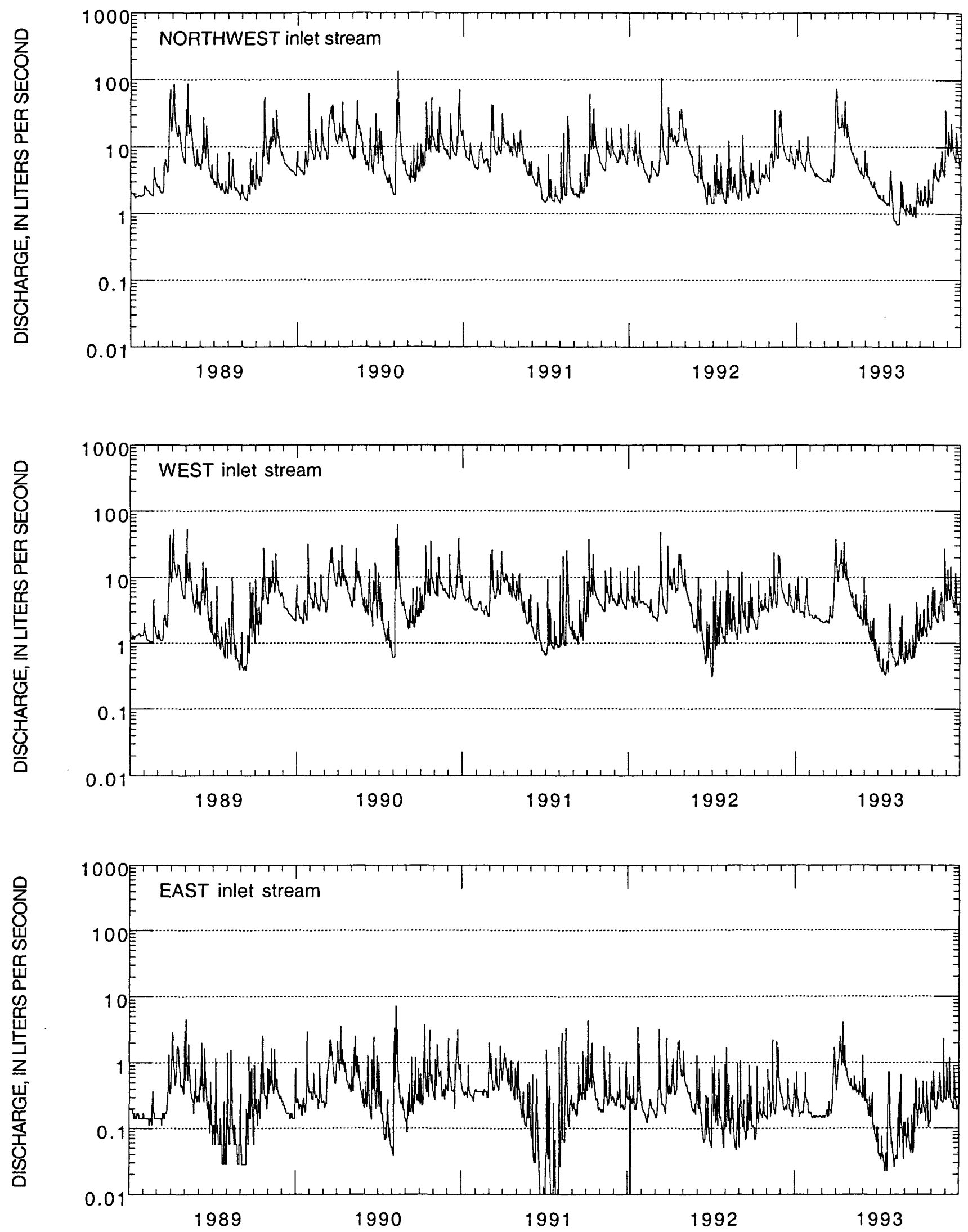

Figure 3. Discharge of the three Mirror Lake inlet streams; Northwest, West and East - Continued 

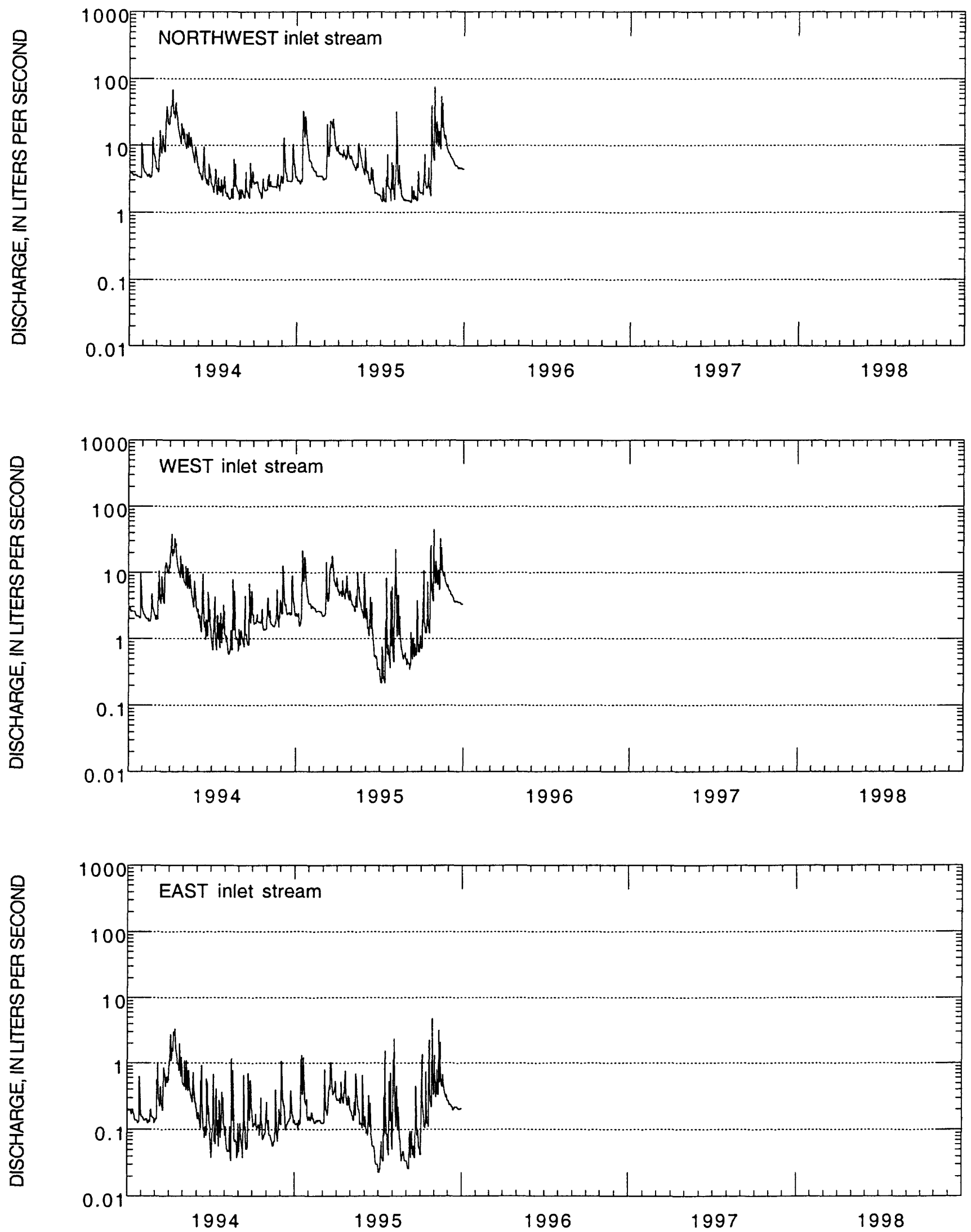

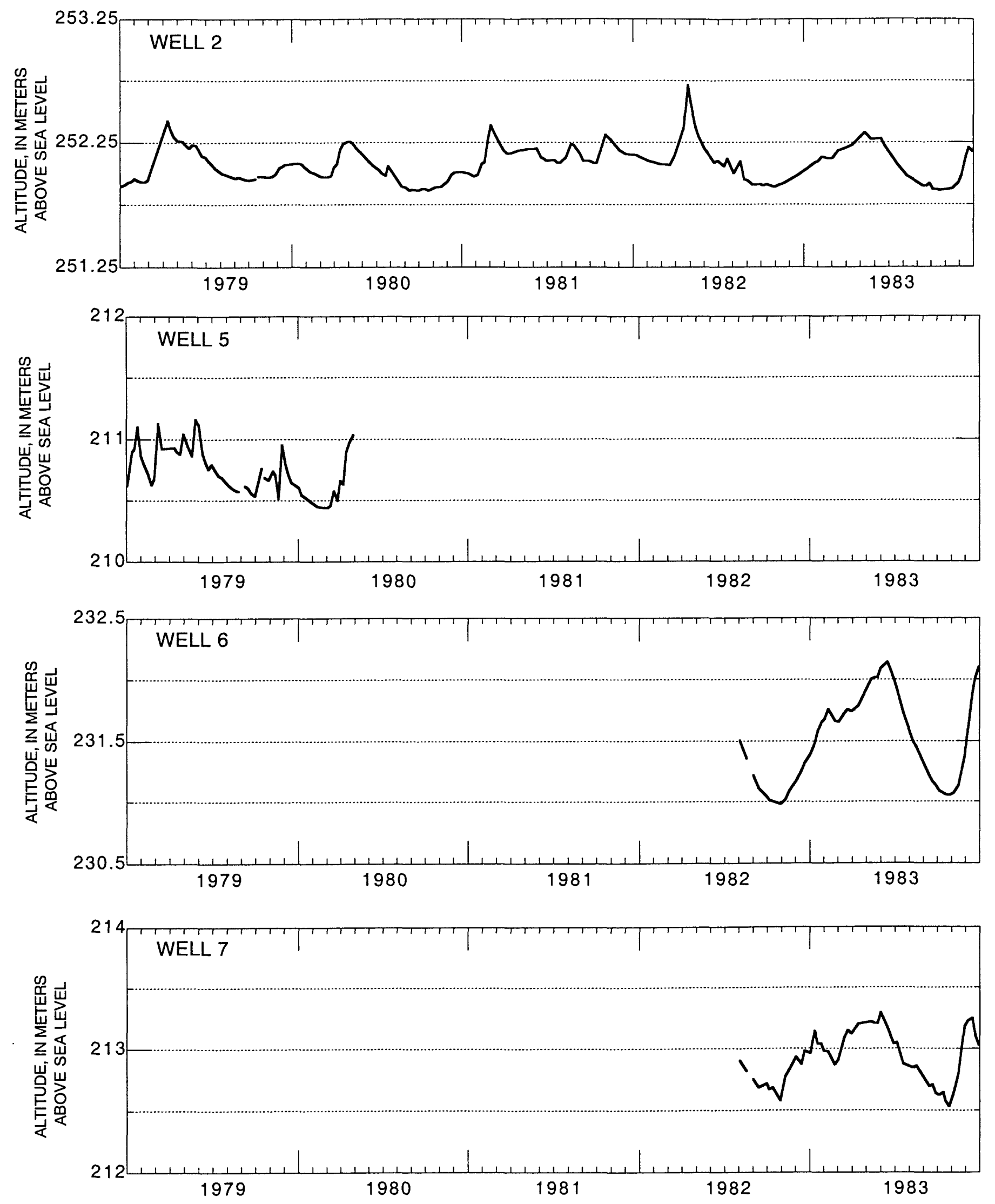

Figure 4. Hydraulic head of the water table at wells 2, 5, 6 and 7. 

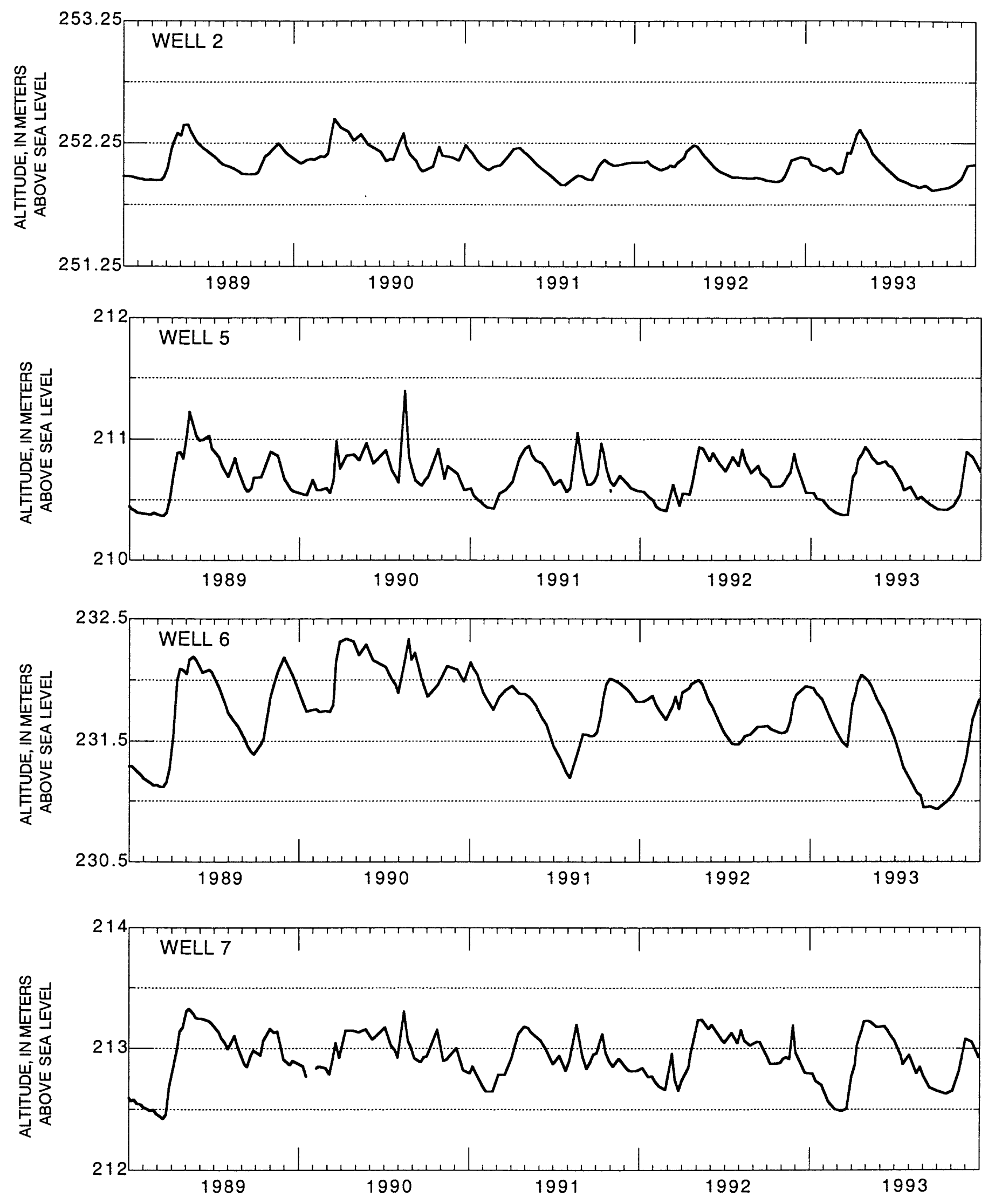

Figure 4. Hydraulic head of the water table at wells 2, 5, 6 and 7. - Continued 

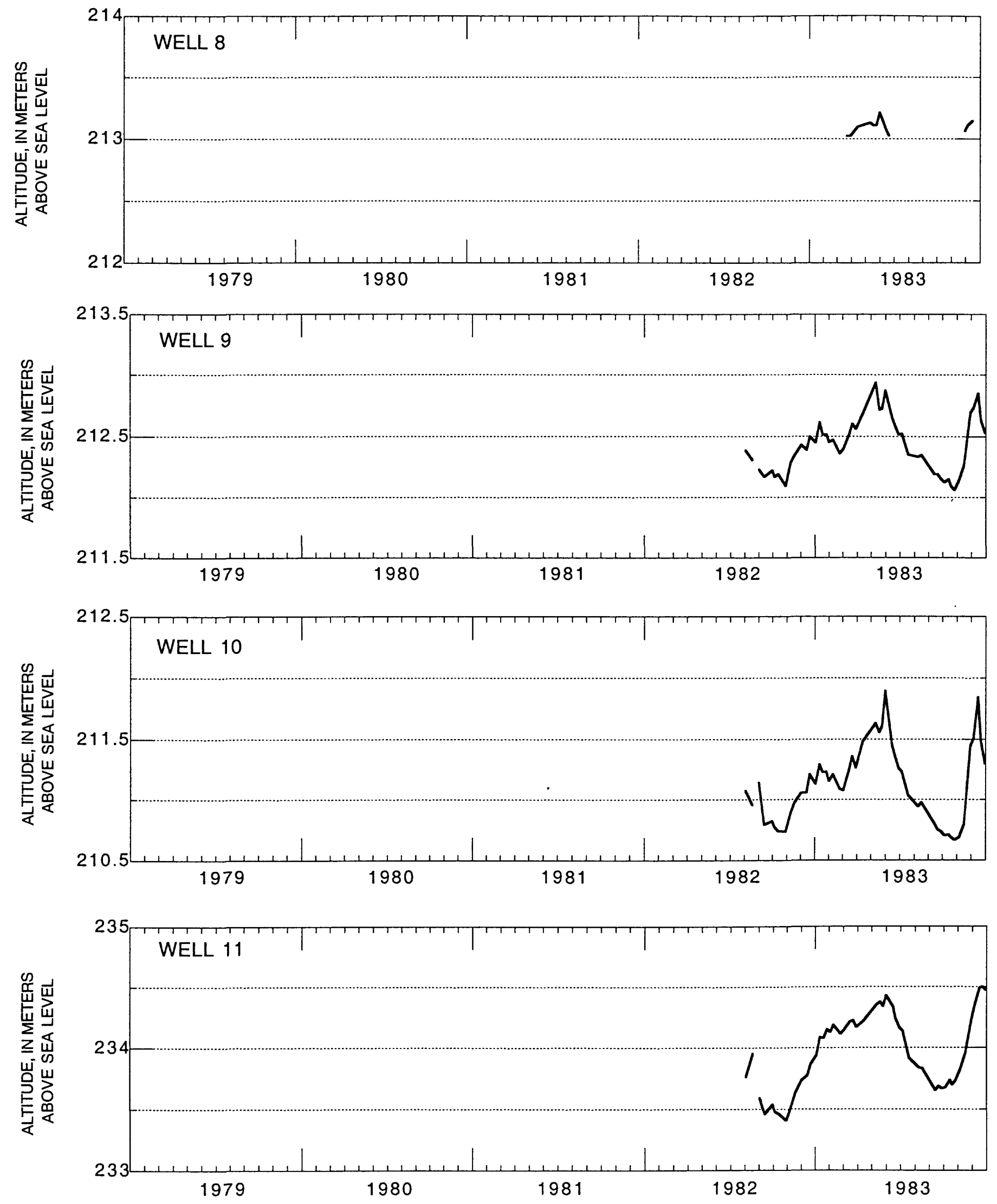

Figure 5. Hydraulic head of the water table at wells 8, 9, 10 and 11. 

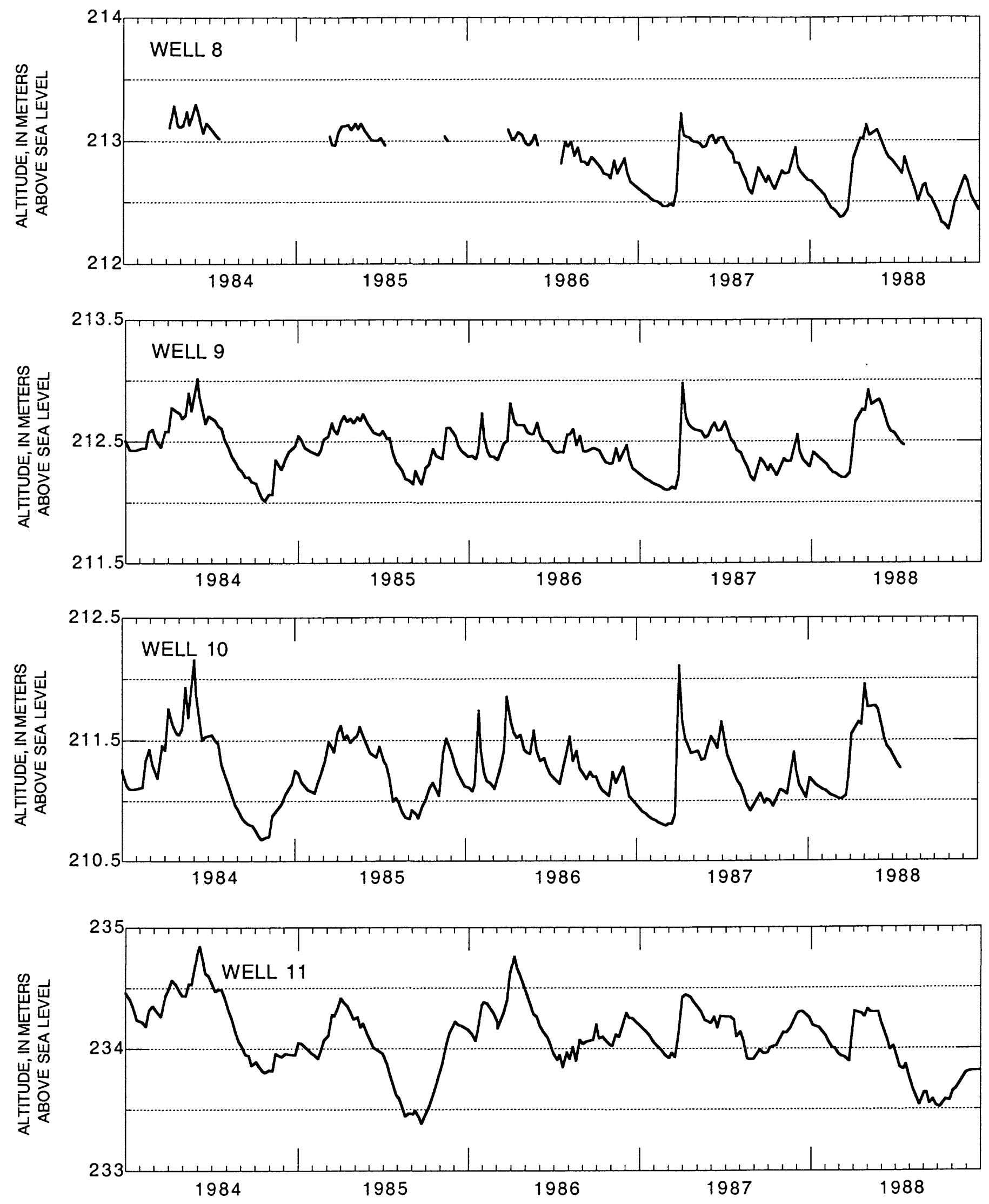

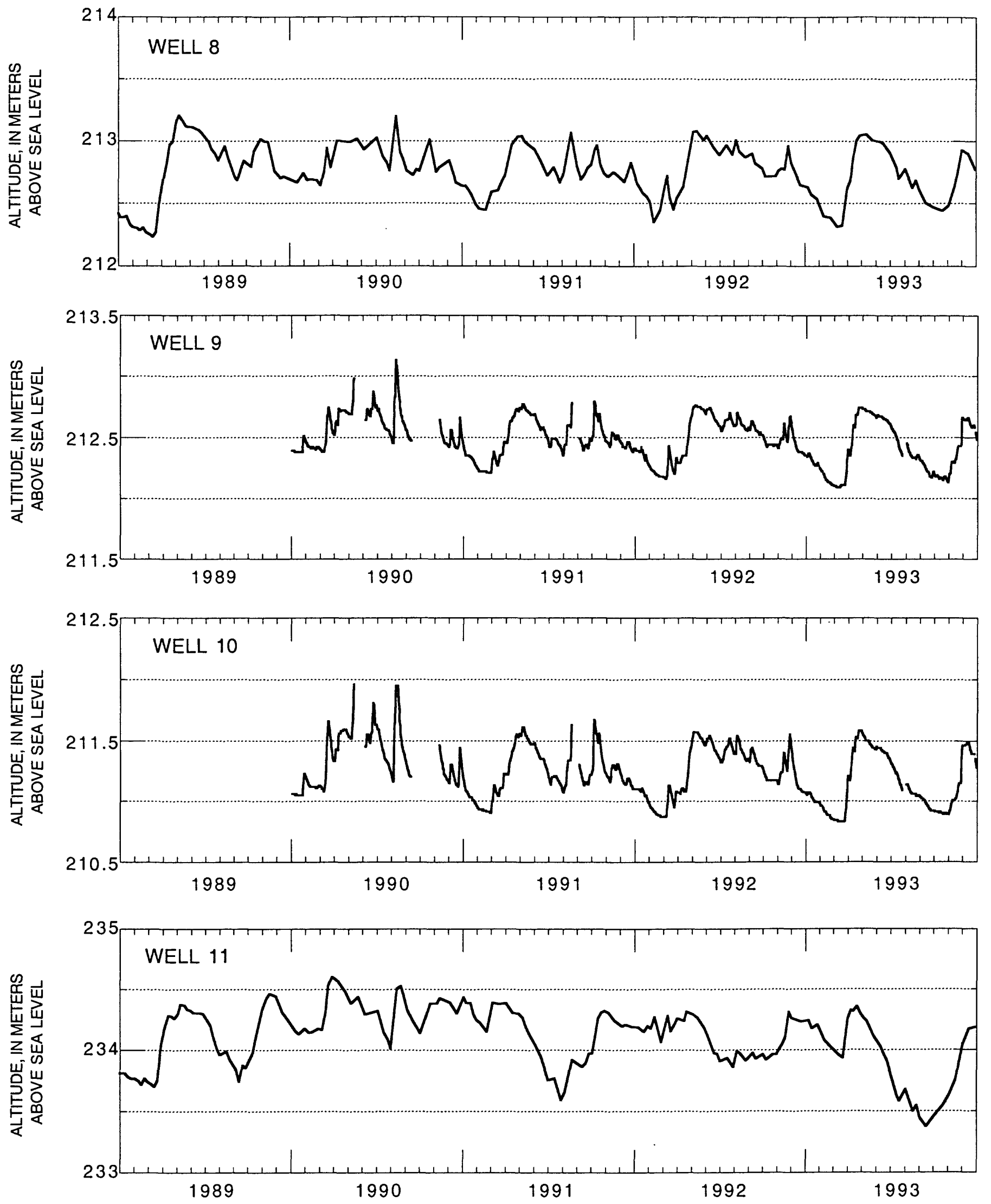

Figure 5. Hydraulic head of the water table at wells 8, 9, 10 and 11. - Continued 

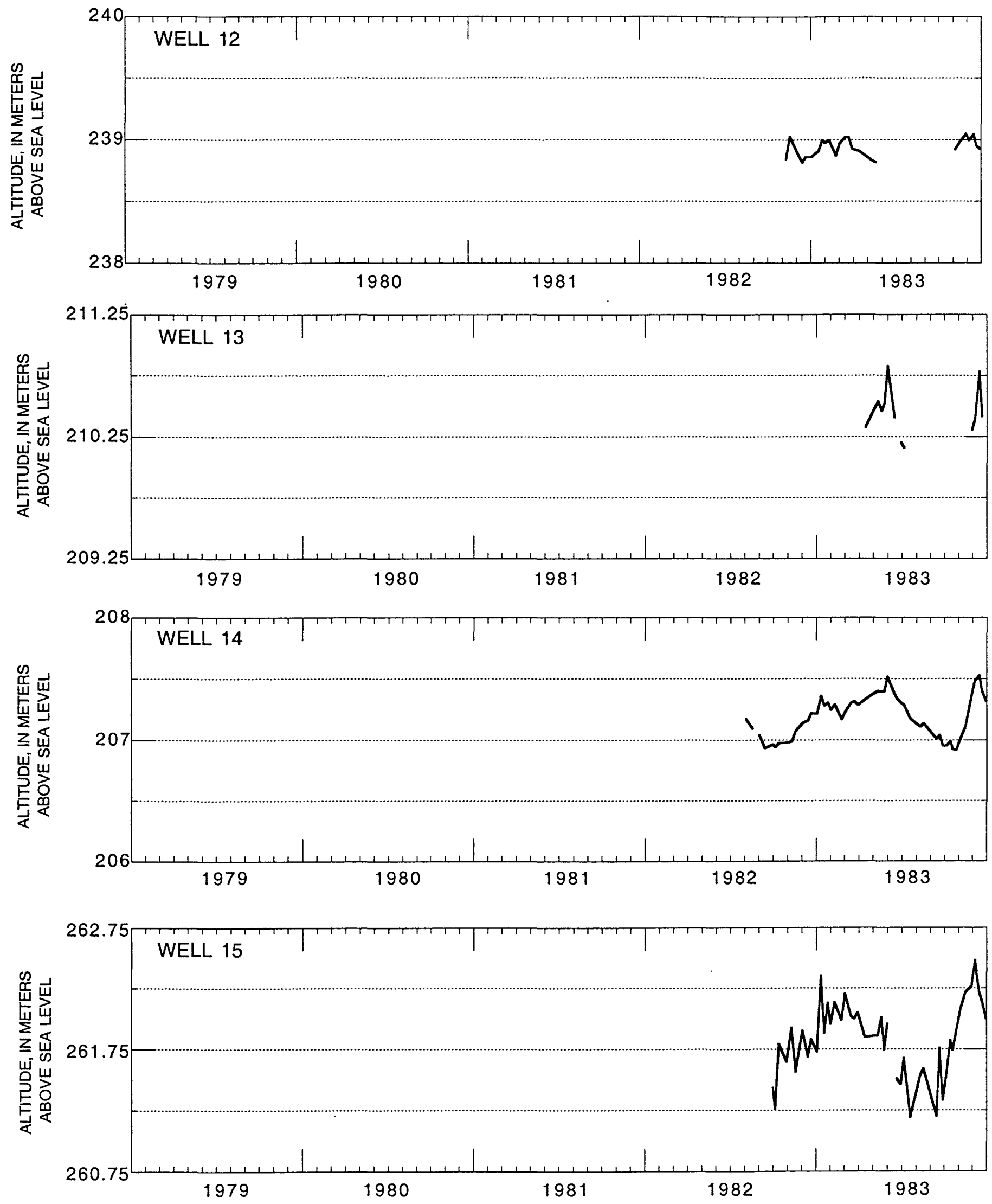

Figure 6. Hydraulic head of the water table at wells $12,13,14$, and 15 . 



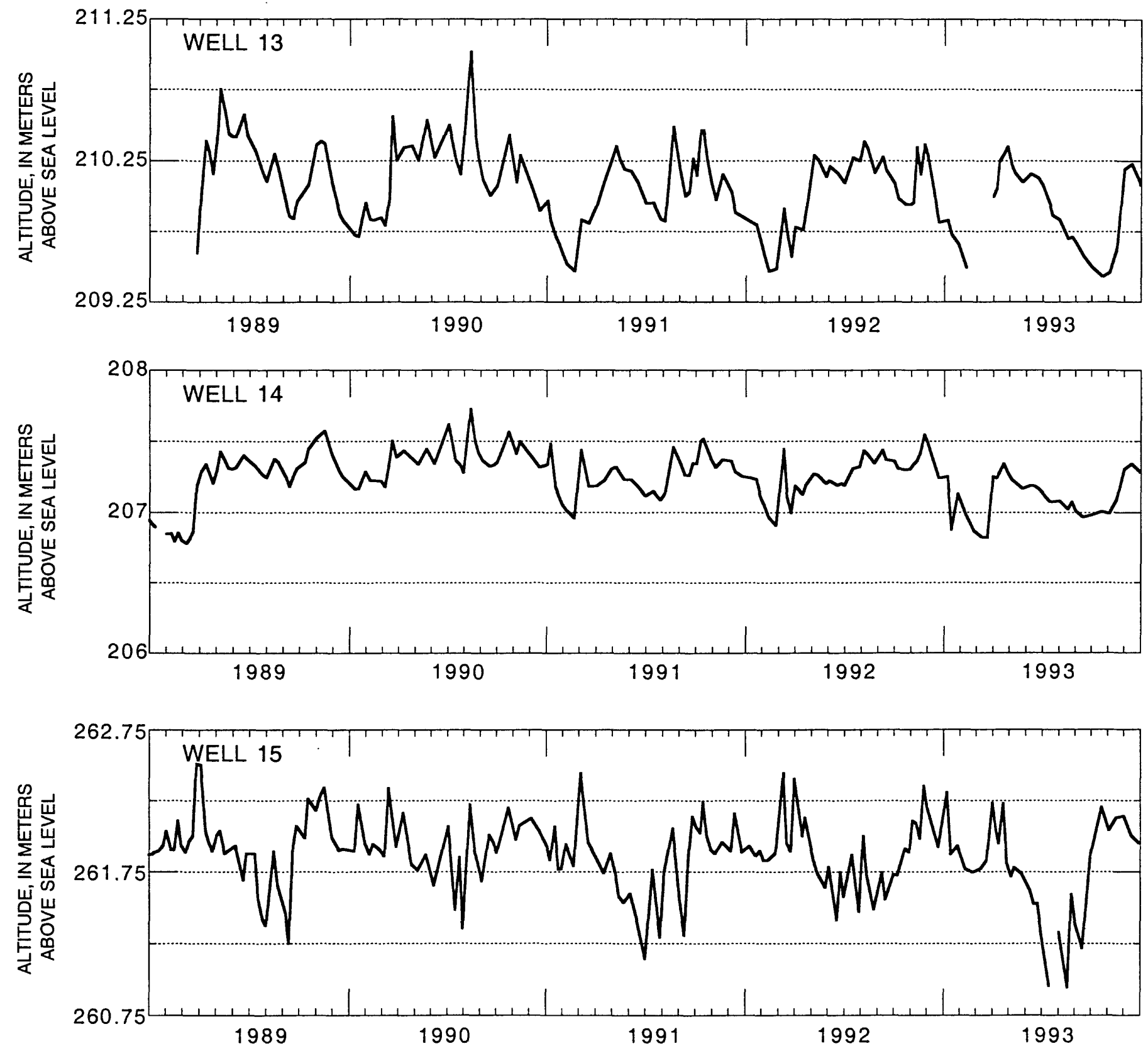

Figure 6. Hydraulic head of the water table at wells 12, 13, 14, and 15 . - Continued 

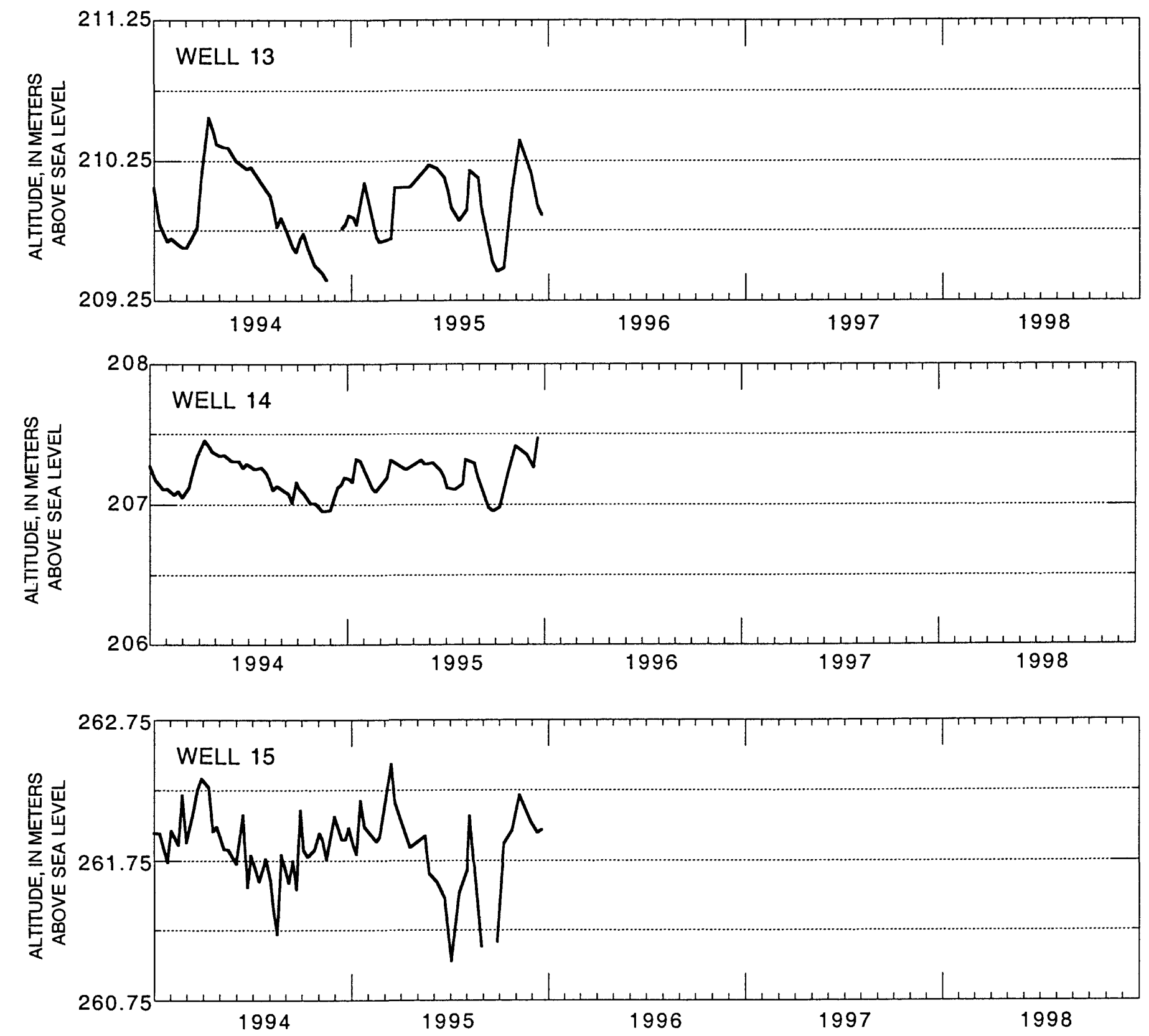


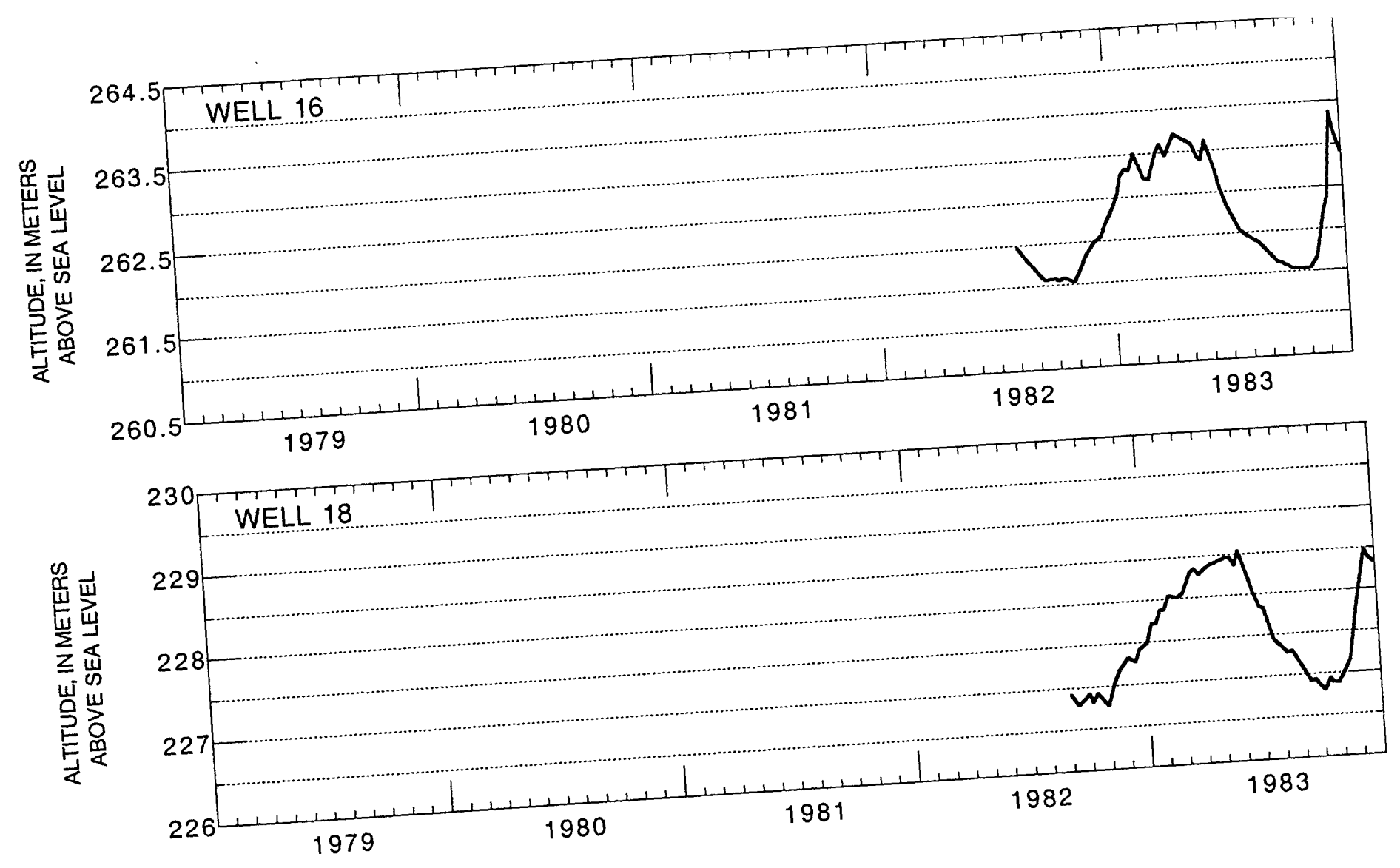

Figure 7. Hydraulic head of the water table at wells $16,18,22$, and 23 . 

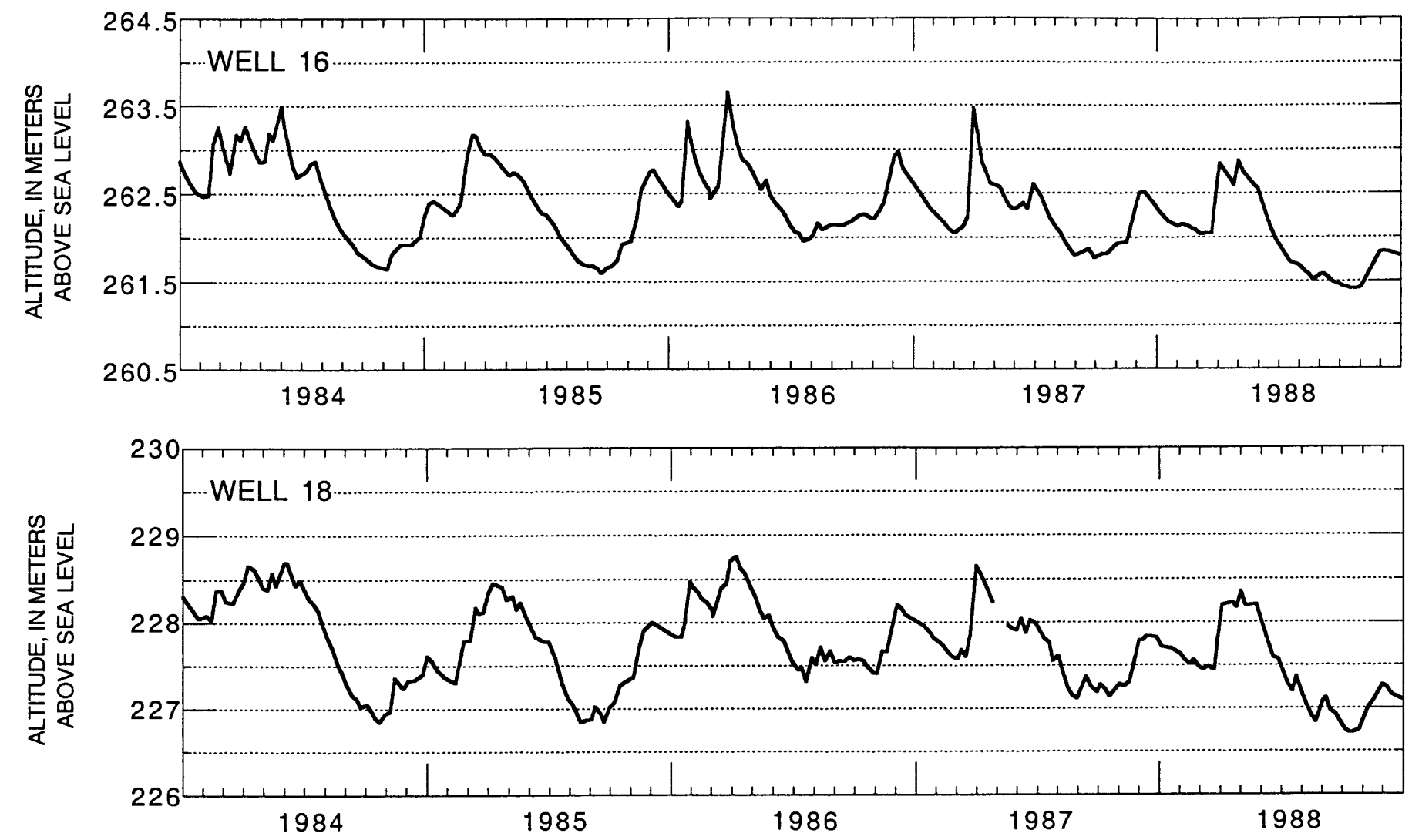

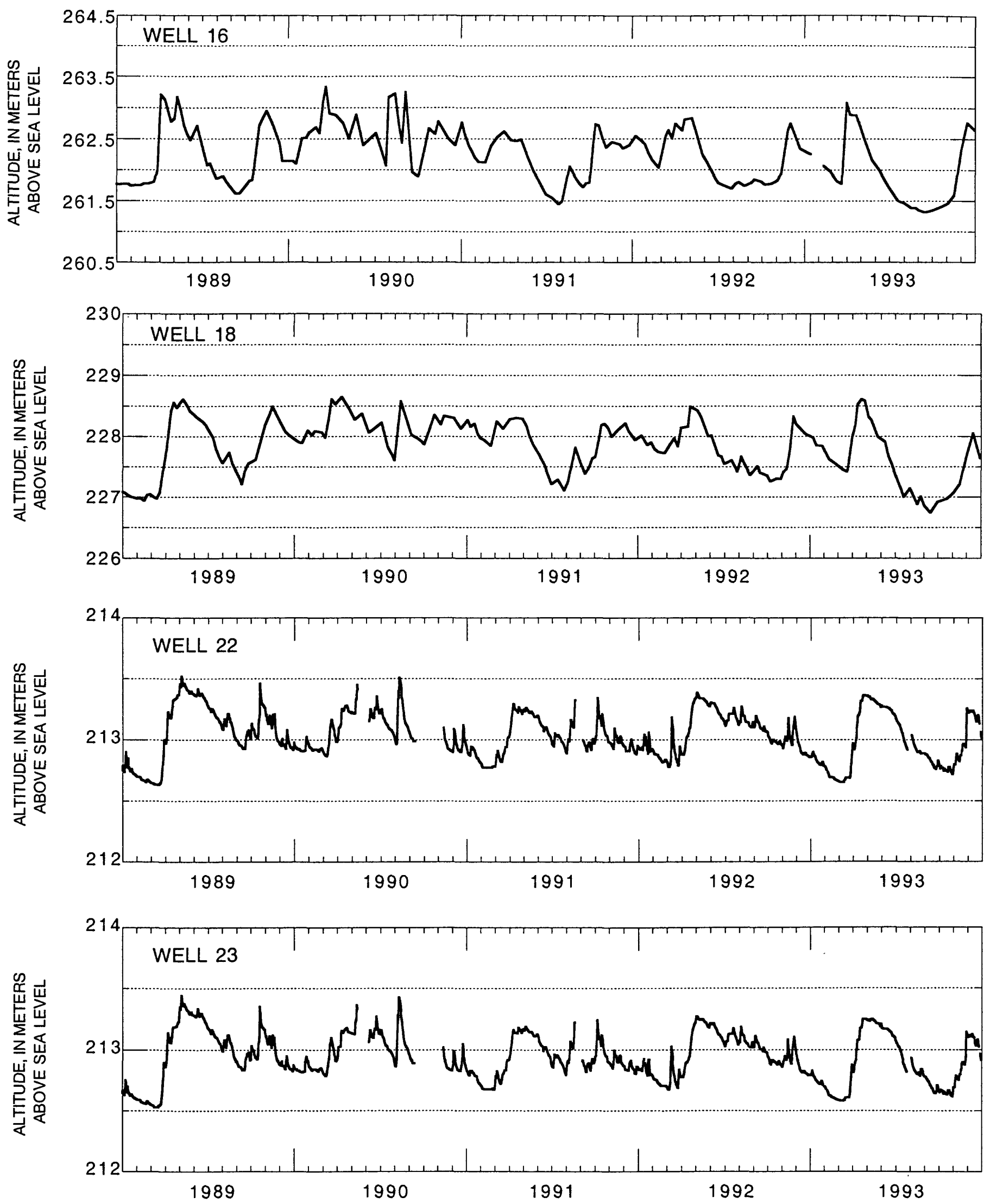

Figure 7. Hydraulic head of the water table at wells 16, 18, 22, and 23 . - Continued 

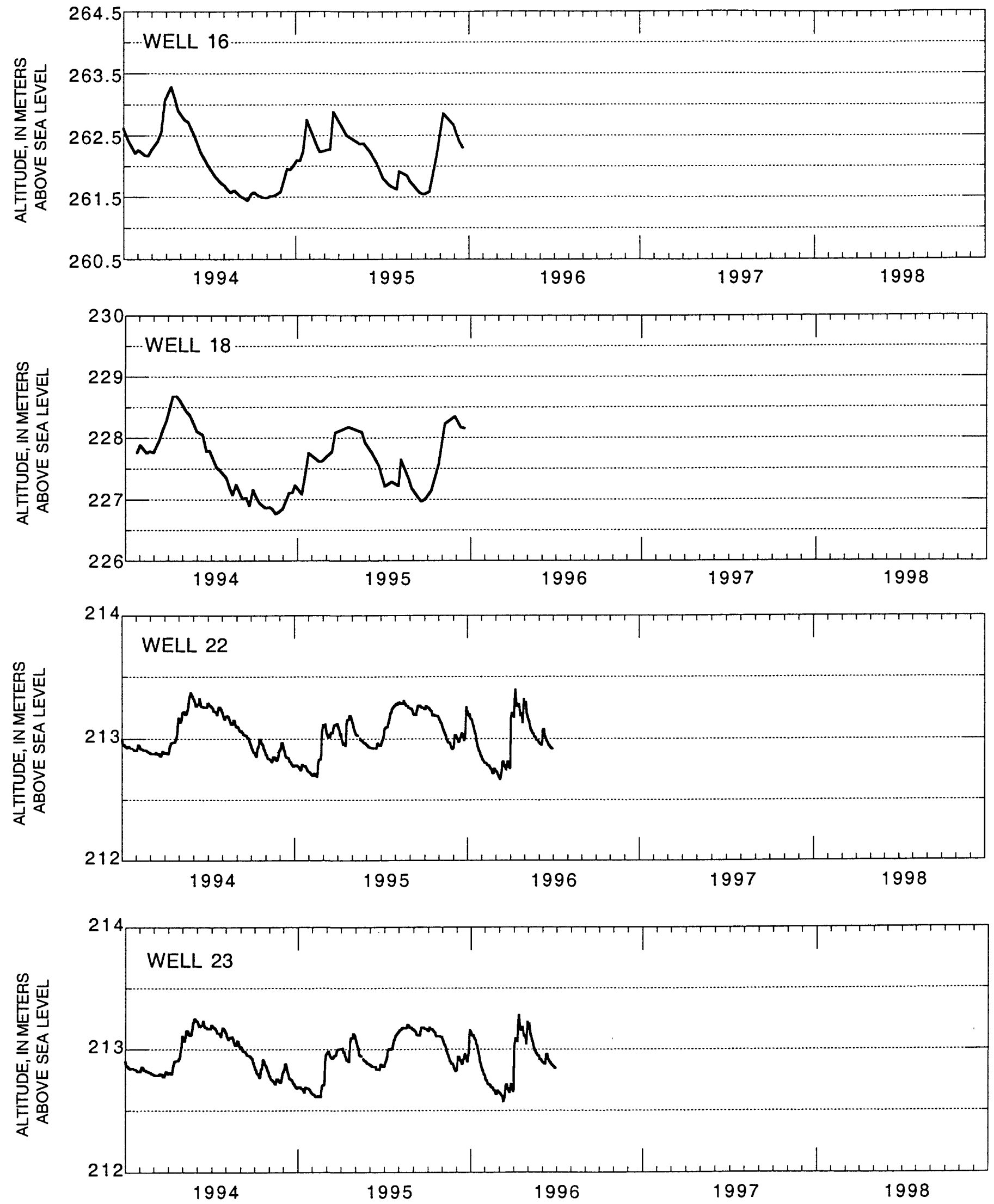


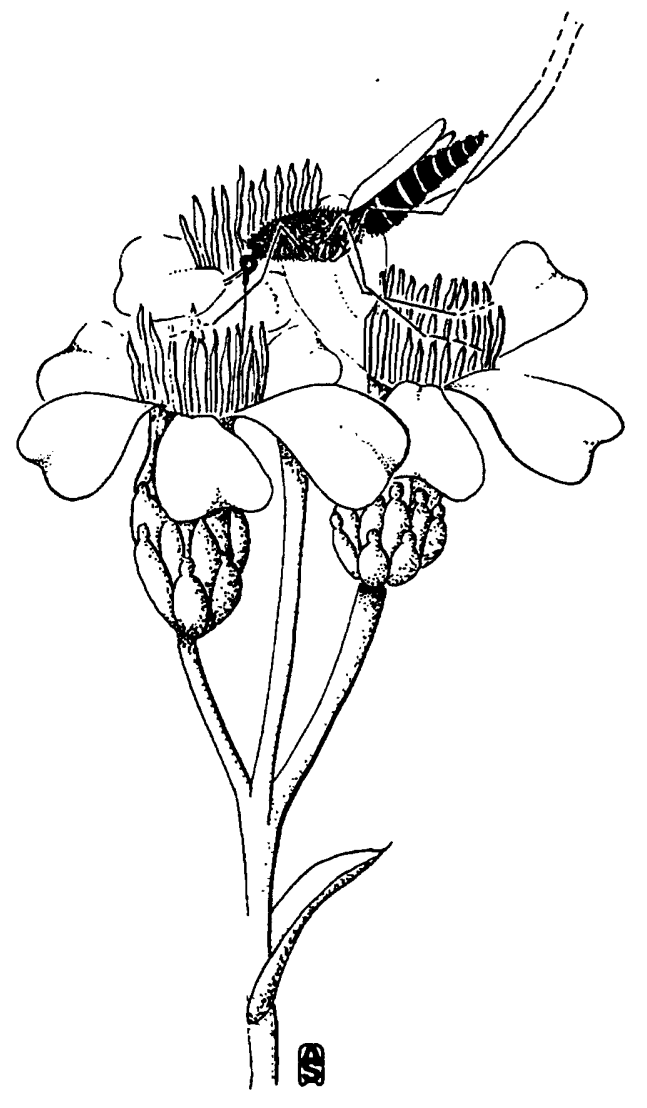



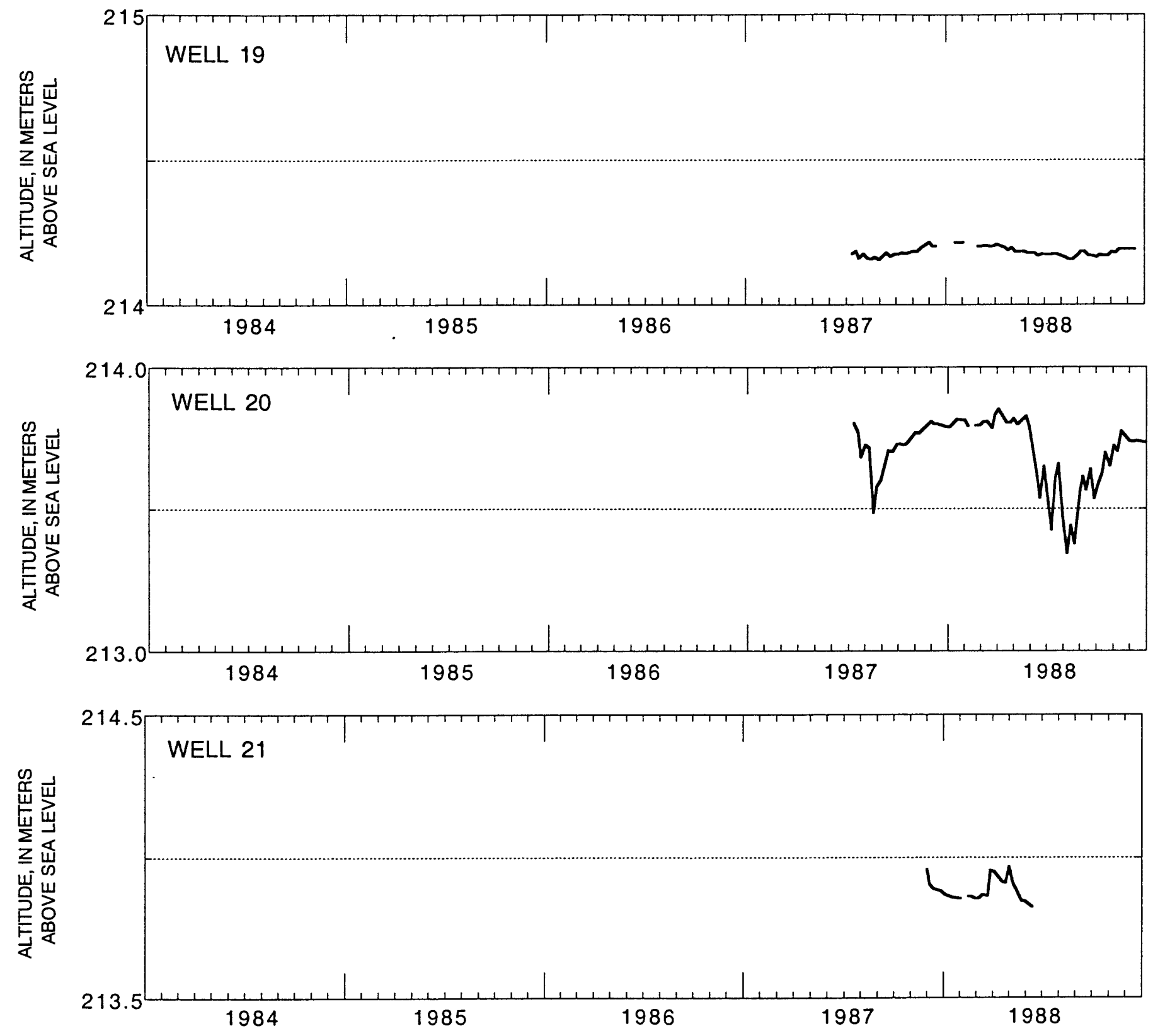

Figure 8. Hydraulic head of the water table at wells 19, 20, and 21 . 

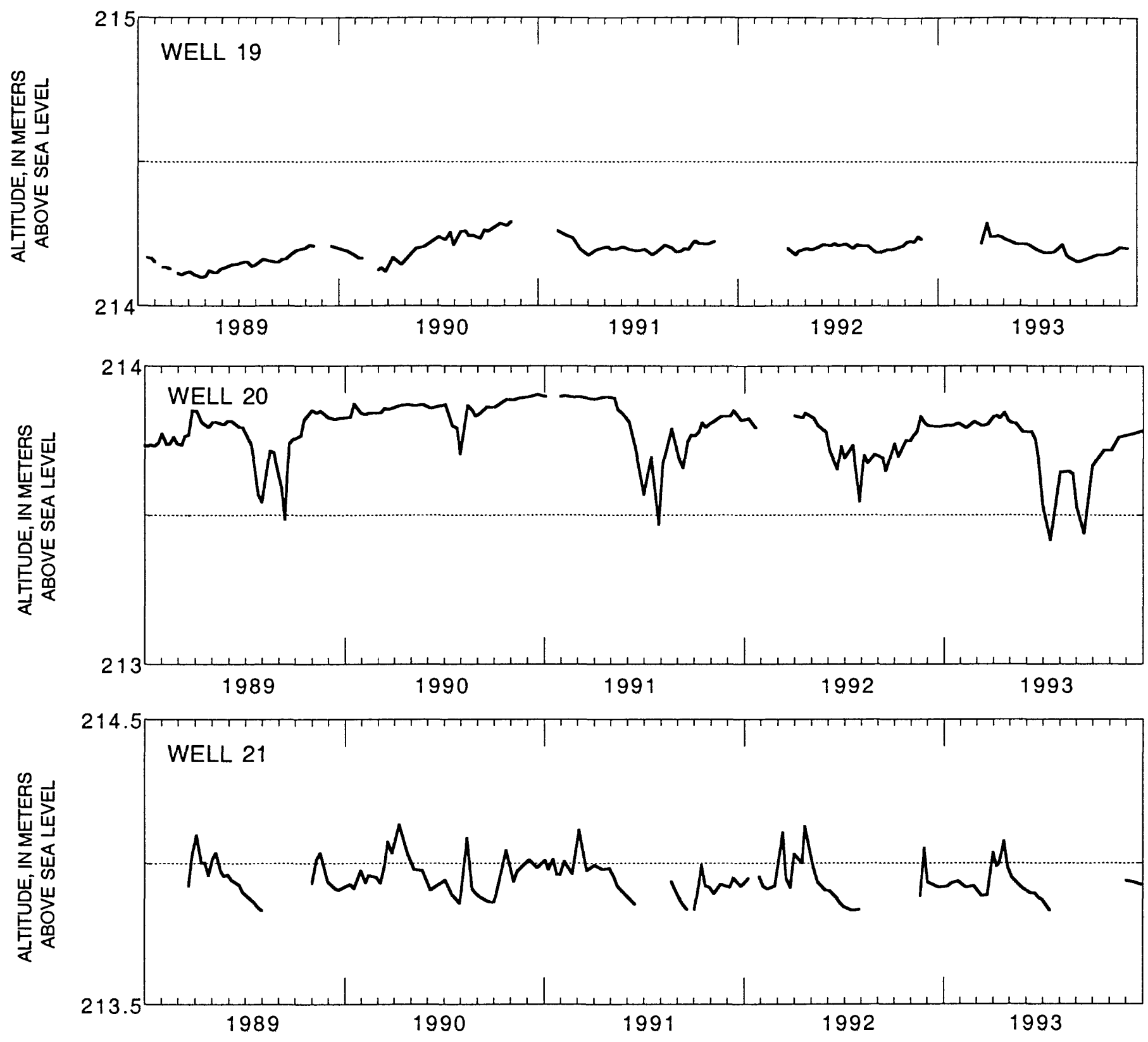

Figure 8. Hydraulic head of the water table at wells 19, 20, and 21. - Continued 

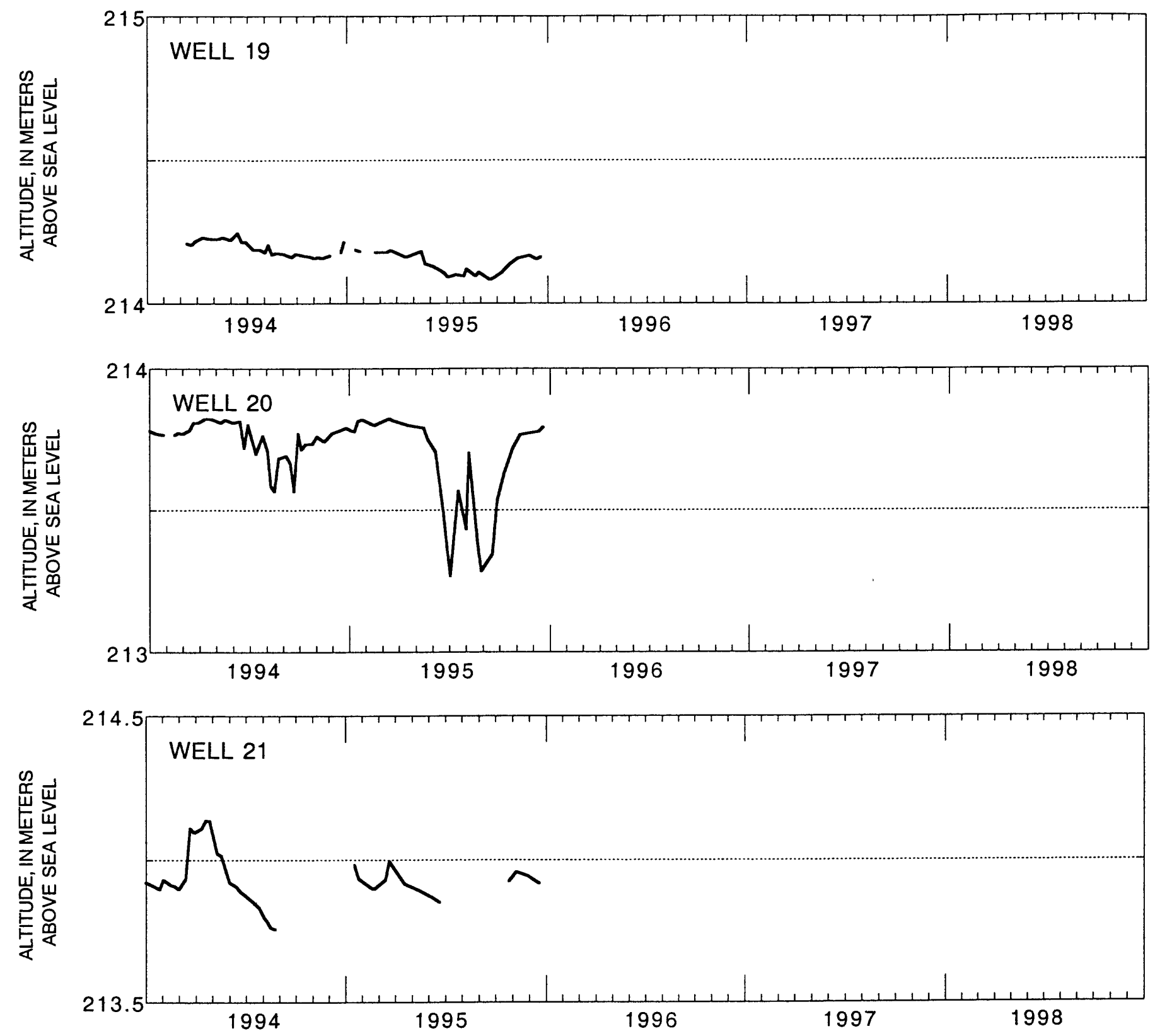

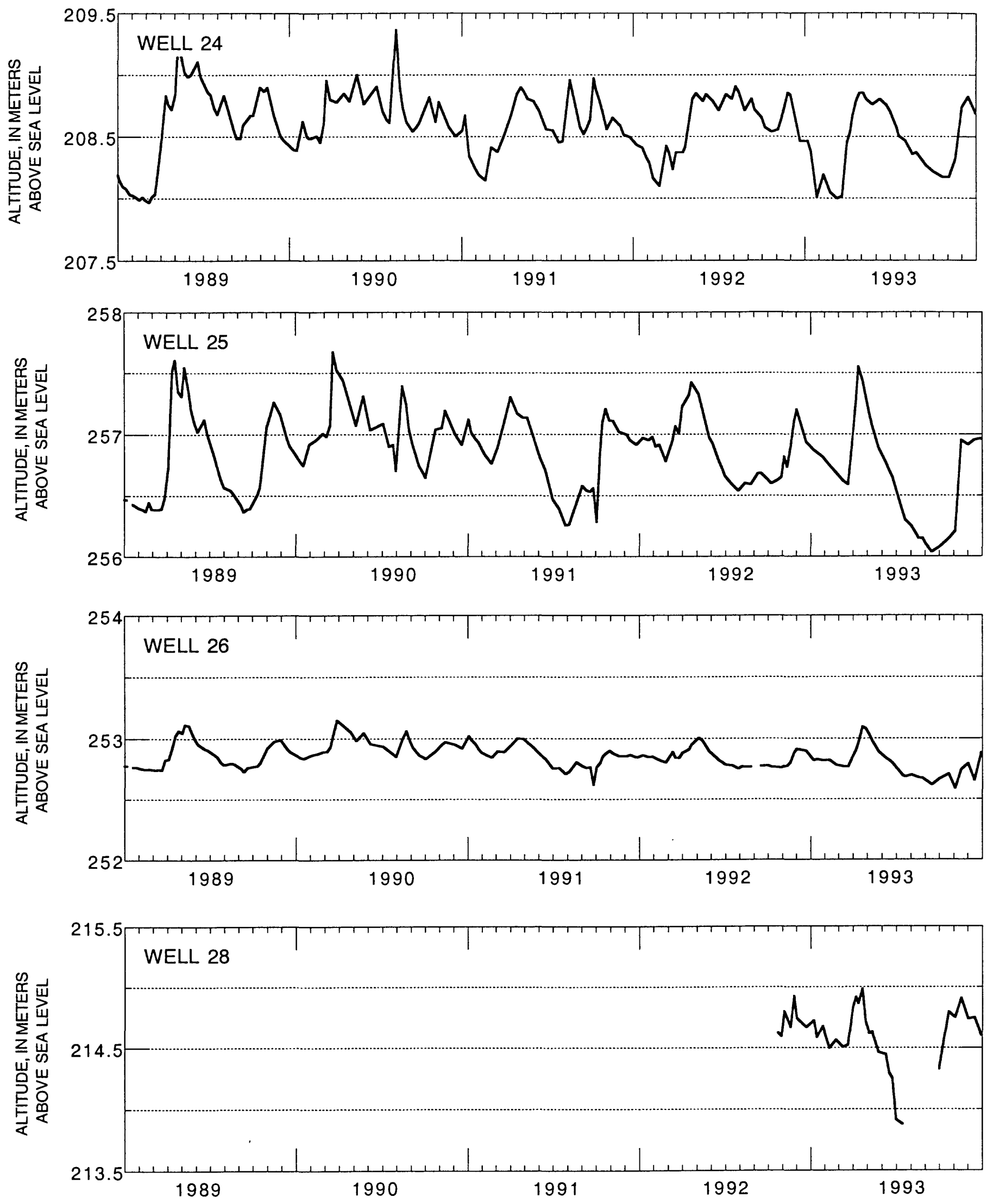

Figure 9. Hydraulic head of the water table at wells $24,25,26$, and 28 . 

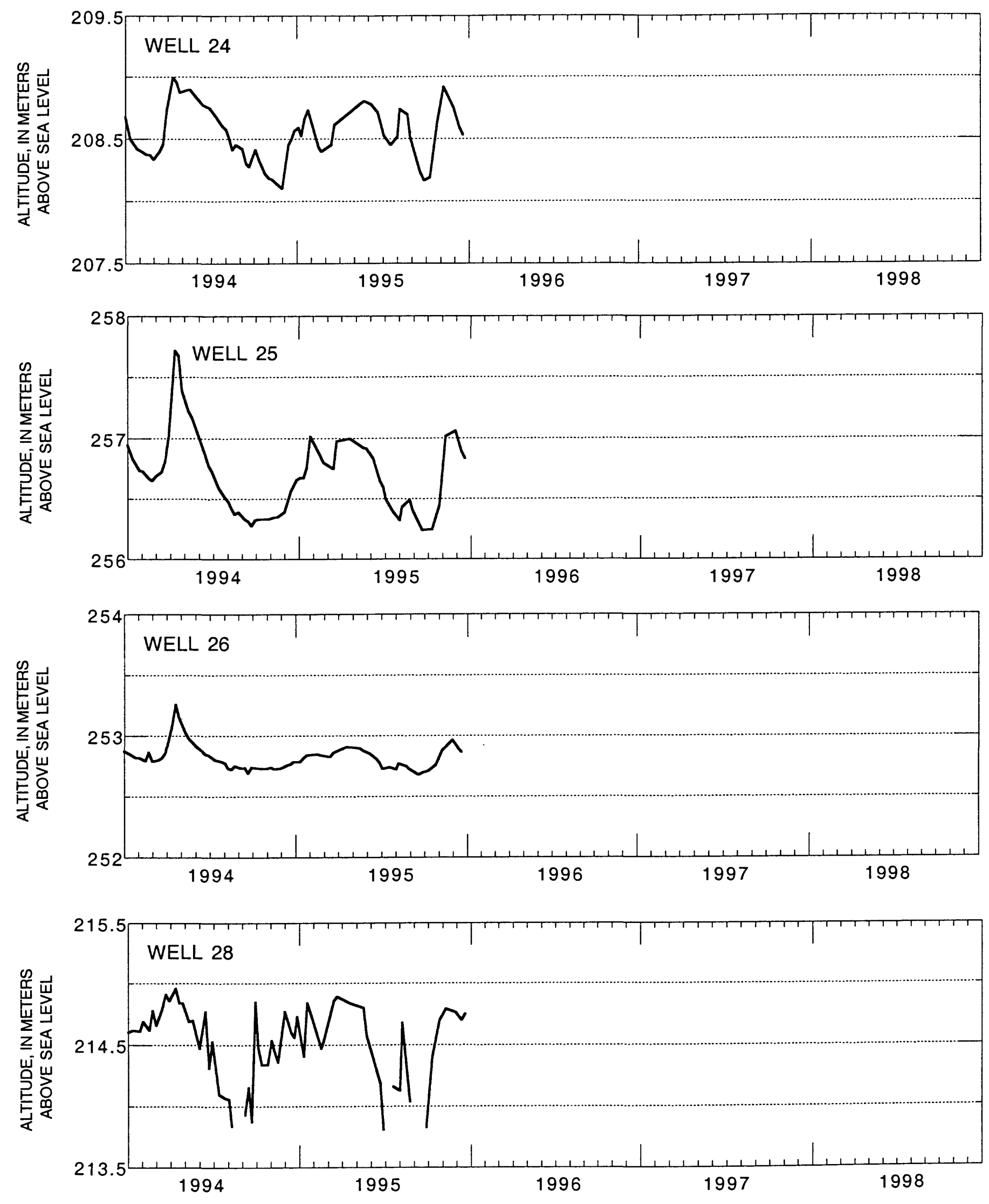

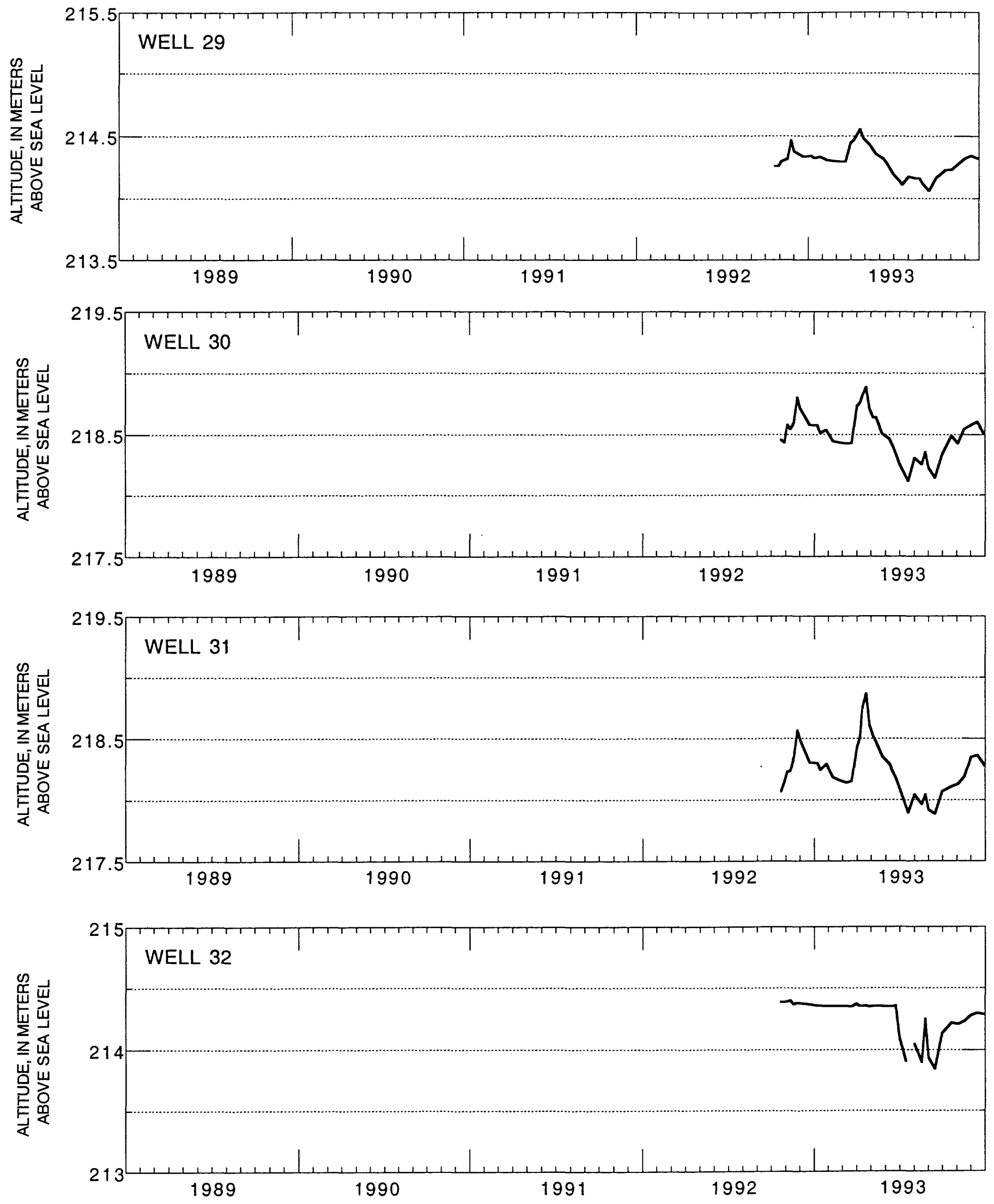

Figure 10. Hydraulic head of the water table at wells 29, 30, 31, and 32 . 

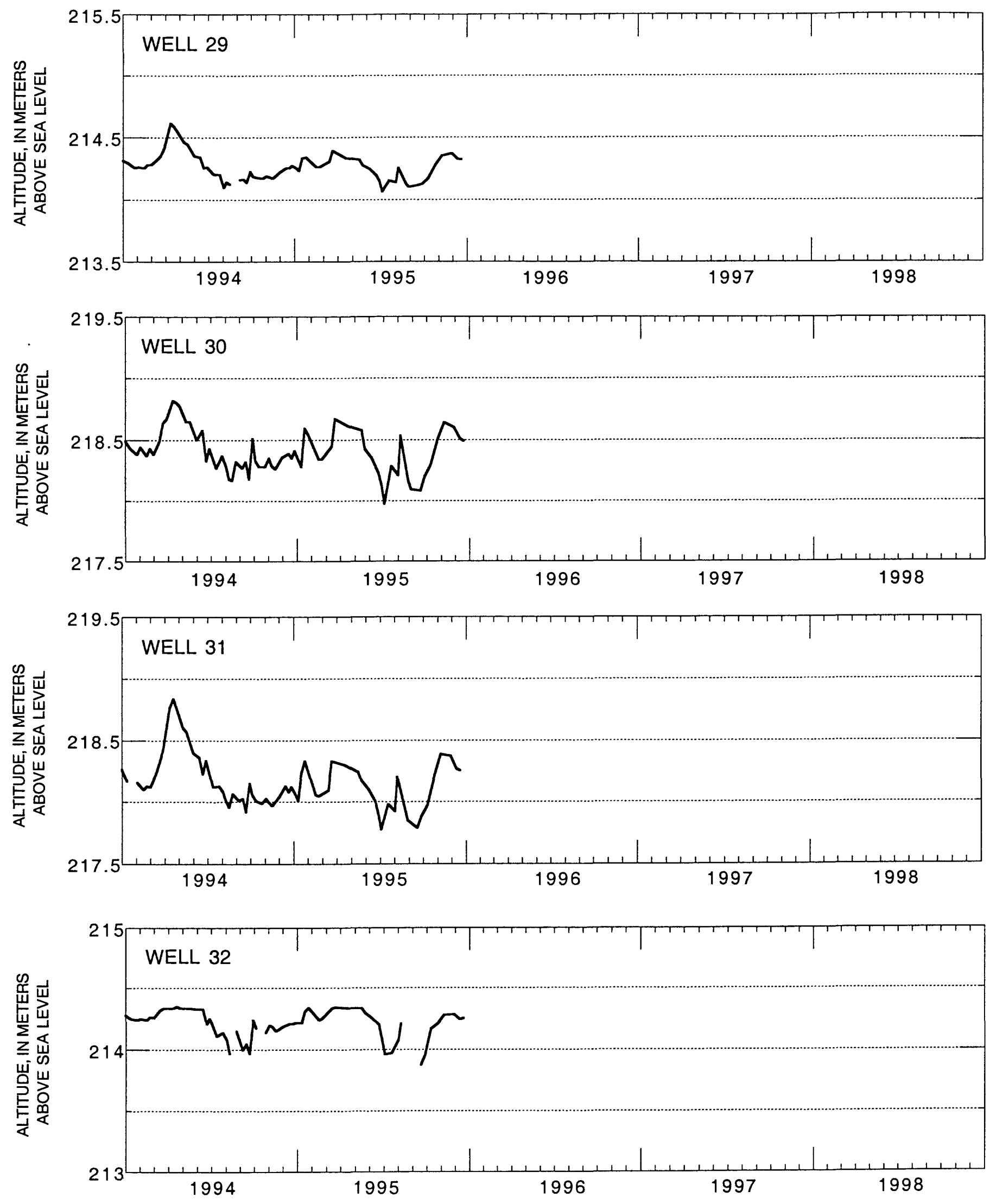

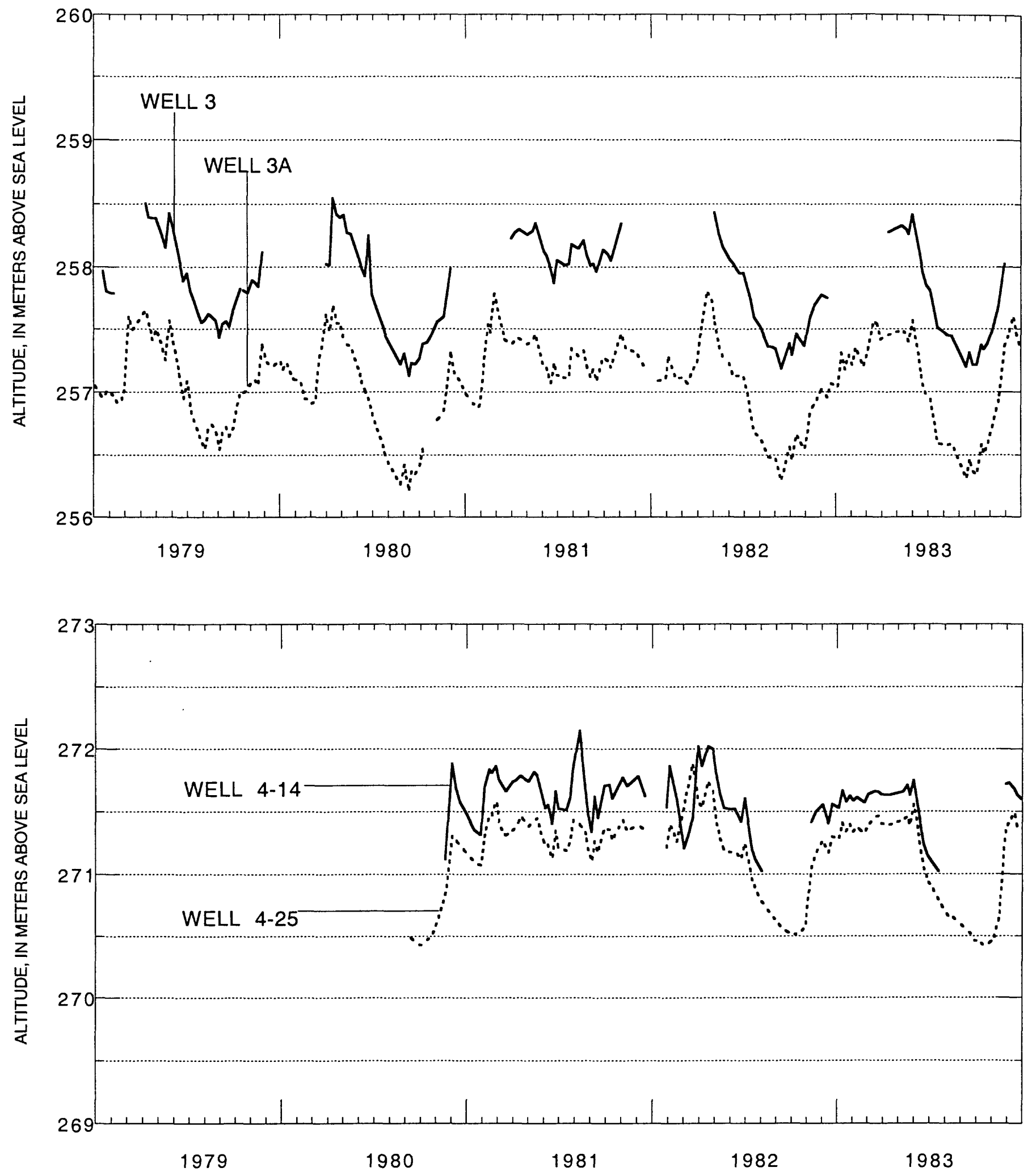

Figure 11. Hydraulic head of the water table at well $3 \mathrm{~A}$ and head $4.3-\mathrm{m}$ deeper at that site in well 3; Hydraulic head of the water table at well 4-14 and head $3.3 \mathrm{~m}$ deeper at that site in well 4-25. Wells 3 and 4-25 were constructed similar to the water-table wells, not as the piezometers where petal baskets and grout were used. 

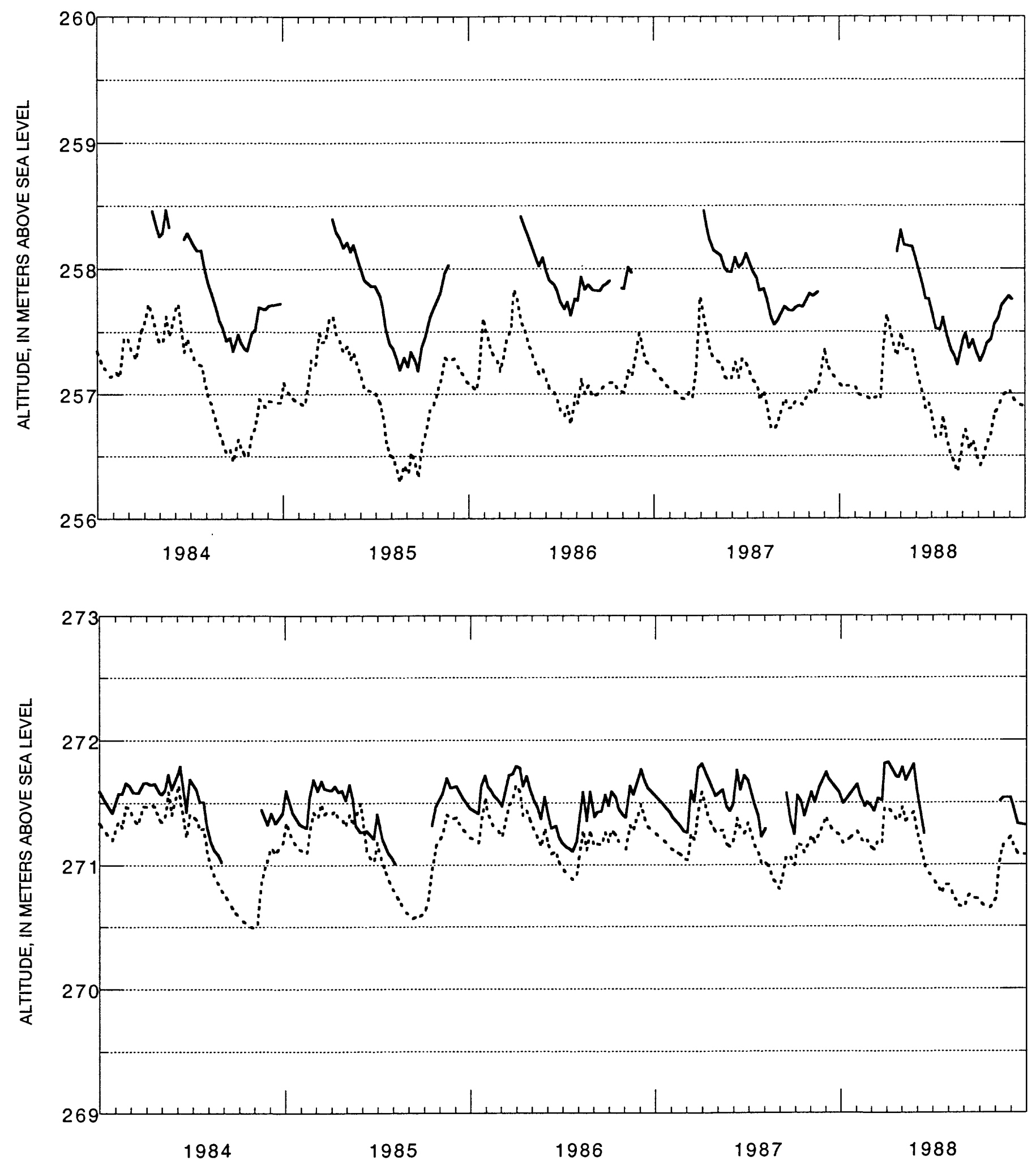

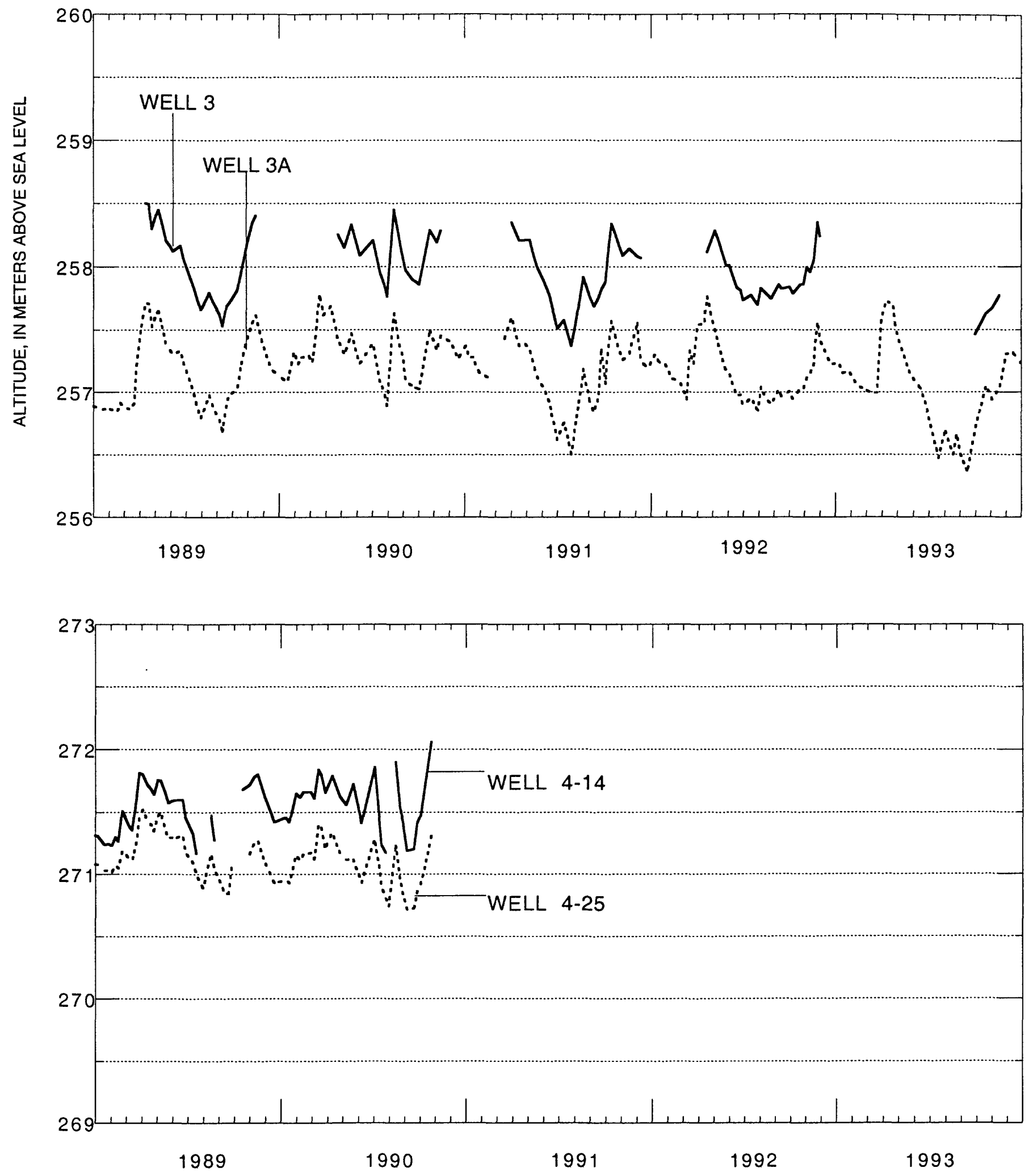

Figure 11. Hydraulic head at wells 3, 3A, 4-14, and 4-25. - Continued 


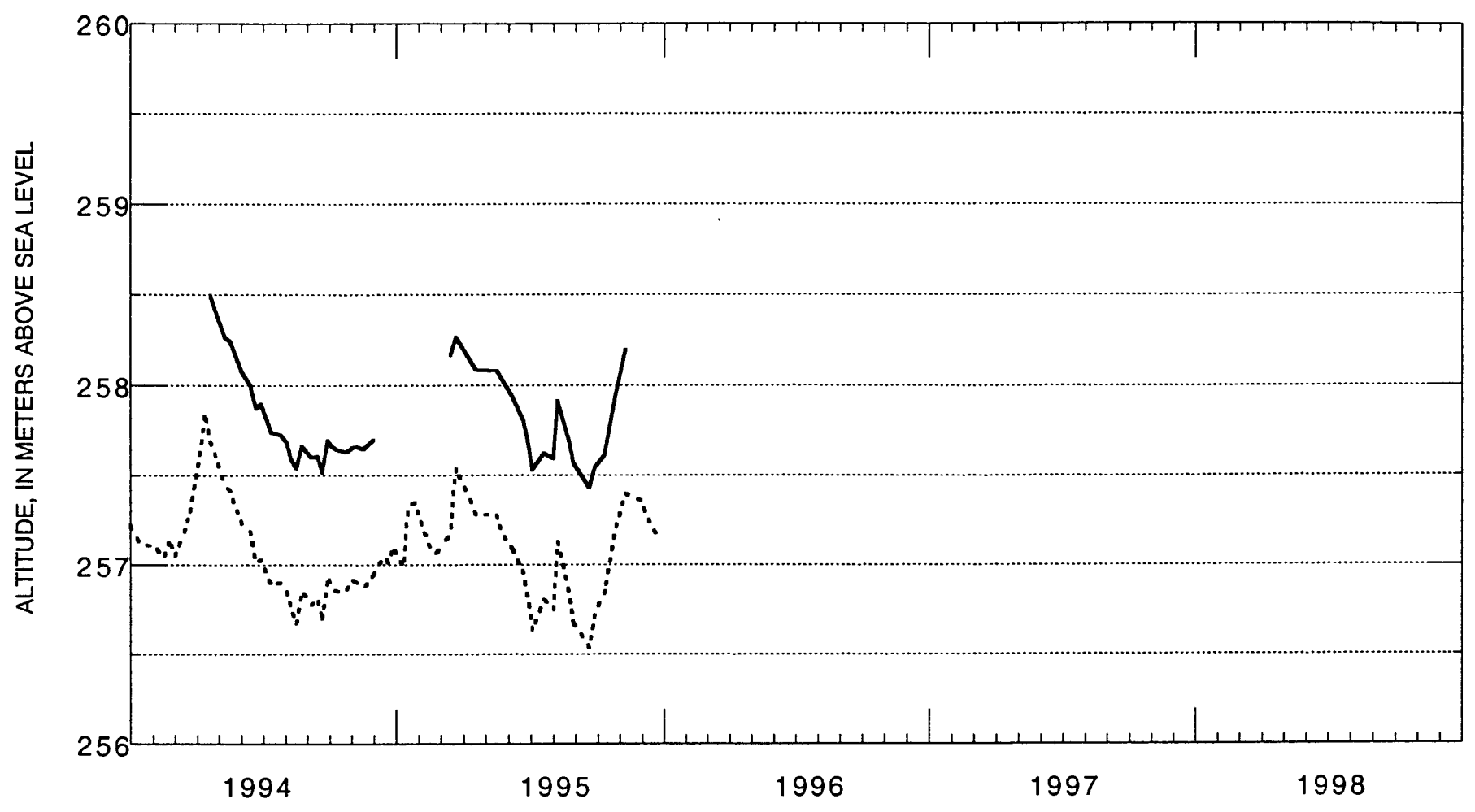



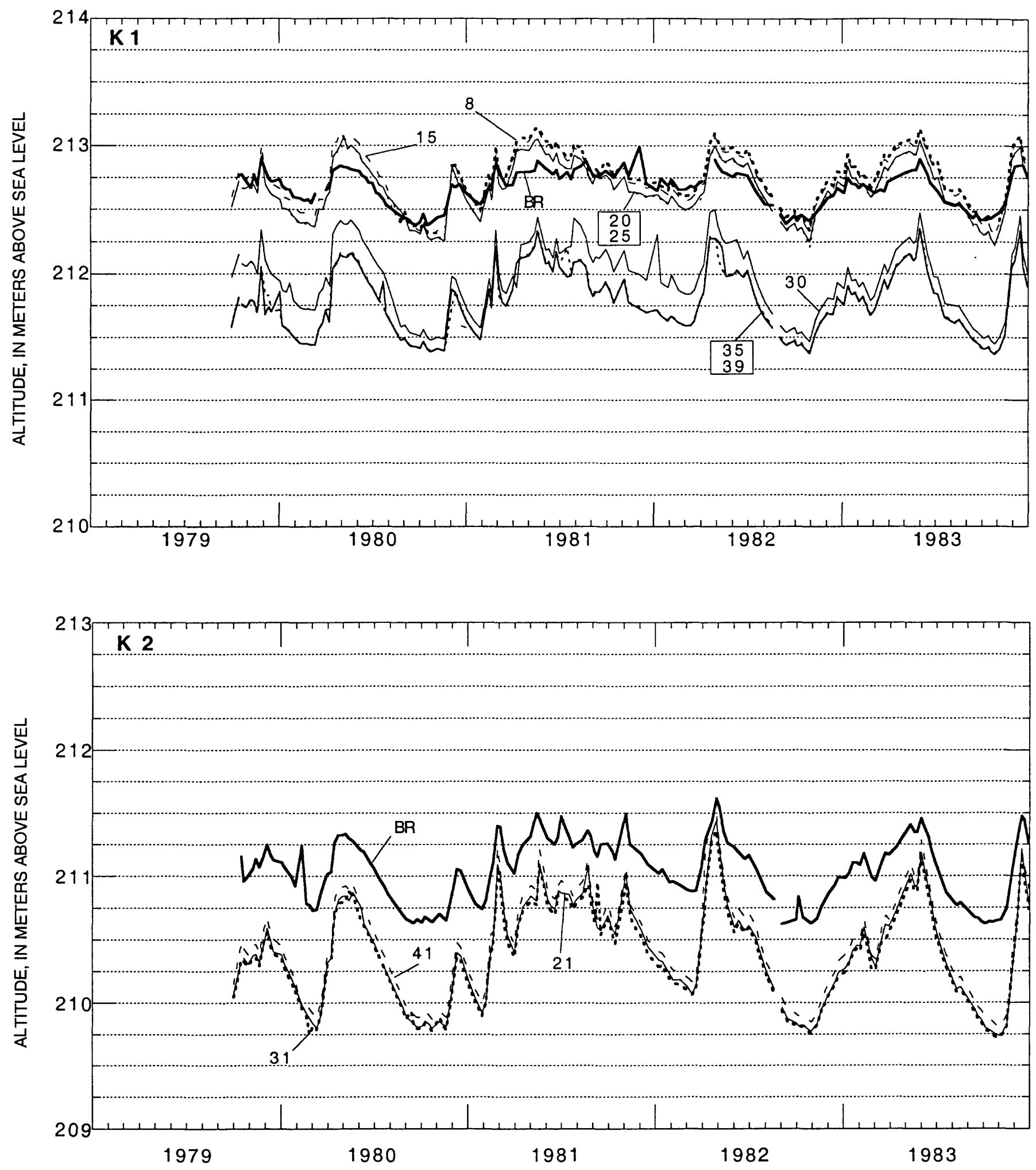

Figure 12. Hydraulic head within the ground-water system at piezometer nests $\mathrm{K} 1$ and $\mathrm{K} 2$. Hydrograph labels indicate the depth of the bottom of the well screen in feet below land surface. The hydrograph labeled 8 represents the hydraulic head of the water table at piezometer nest K1. Head in bedrock is indicated by the hydrograph labeled $B R$. 

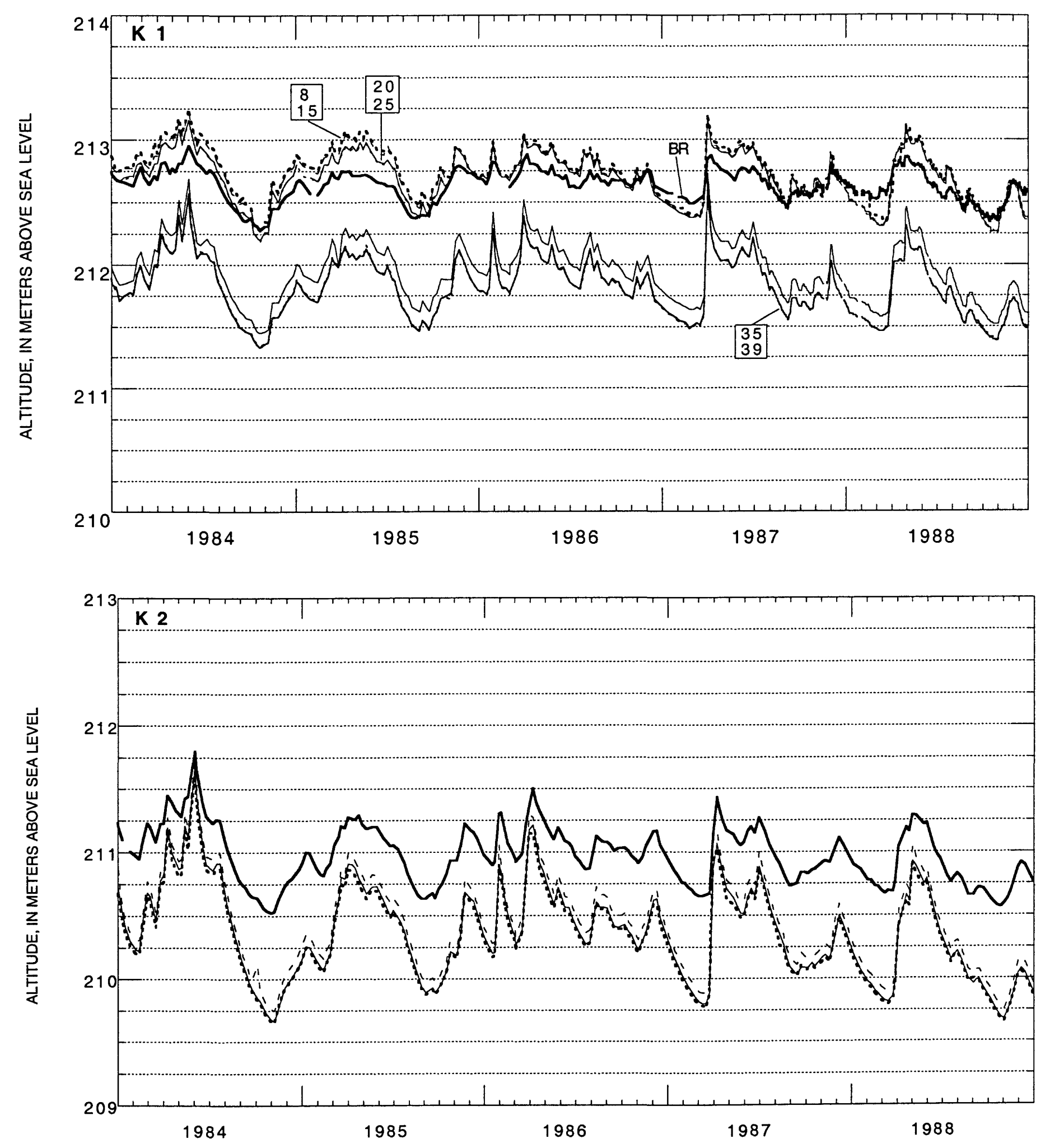

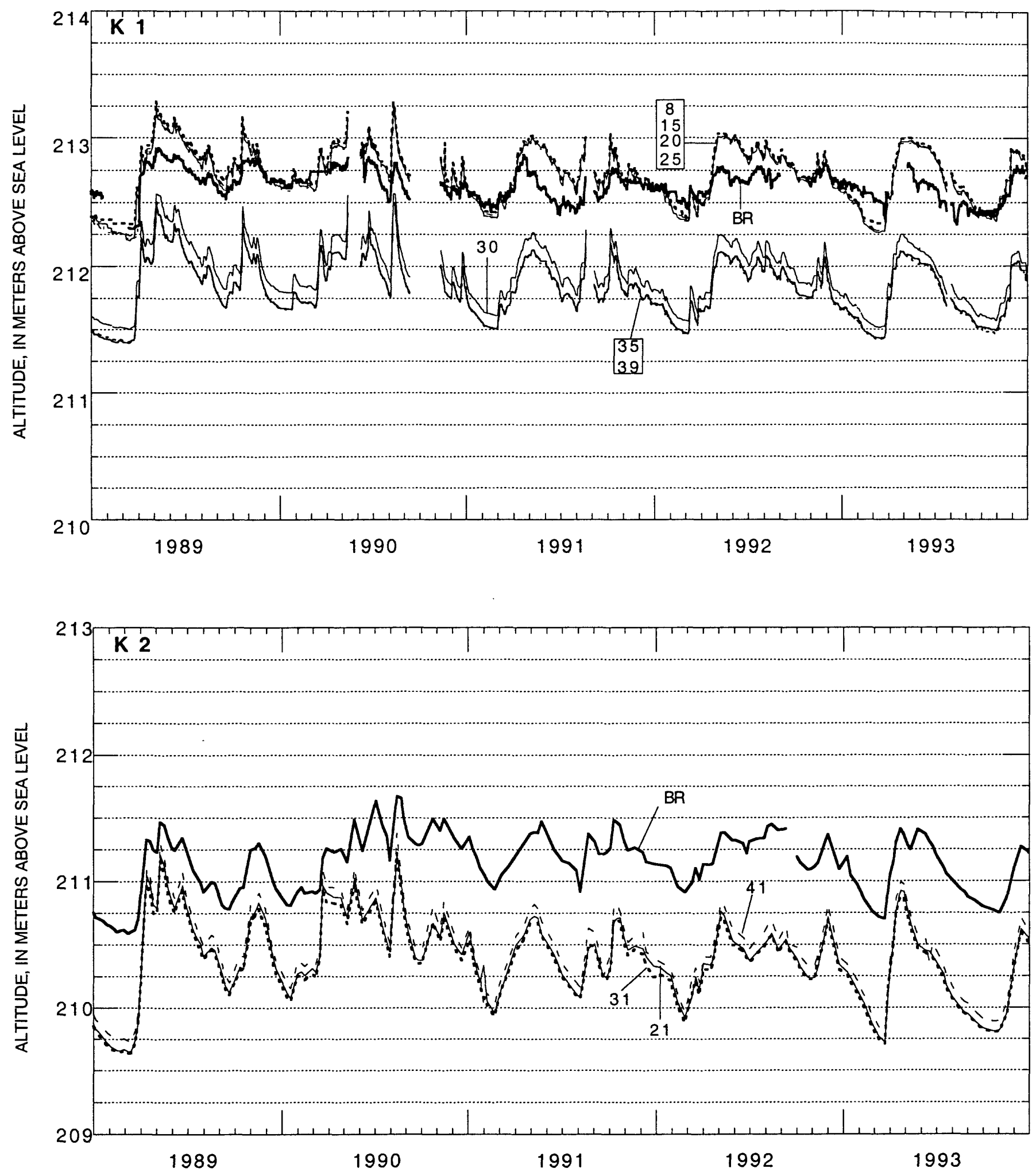

Figure 12. Hydraulic head within the ground-water system at piezometer nests $\mathrm{K} 1$ and $\mathrm{K} 2$. - Continued 

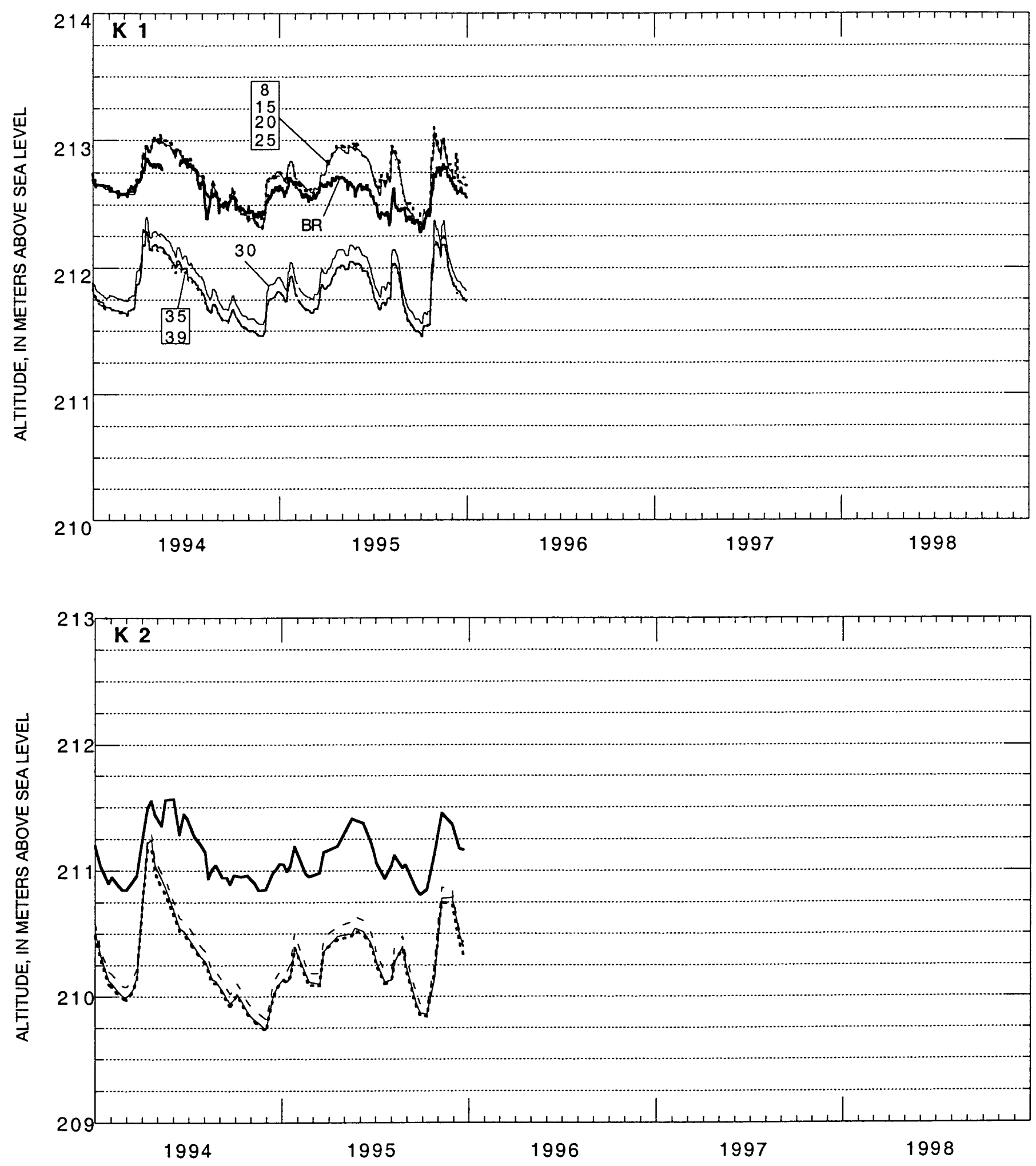

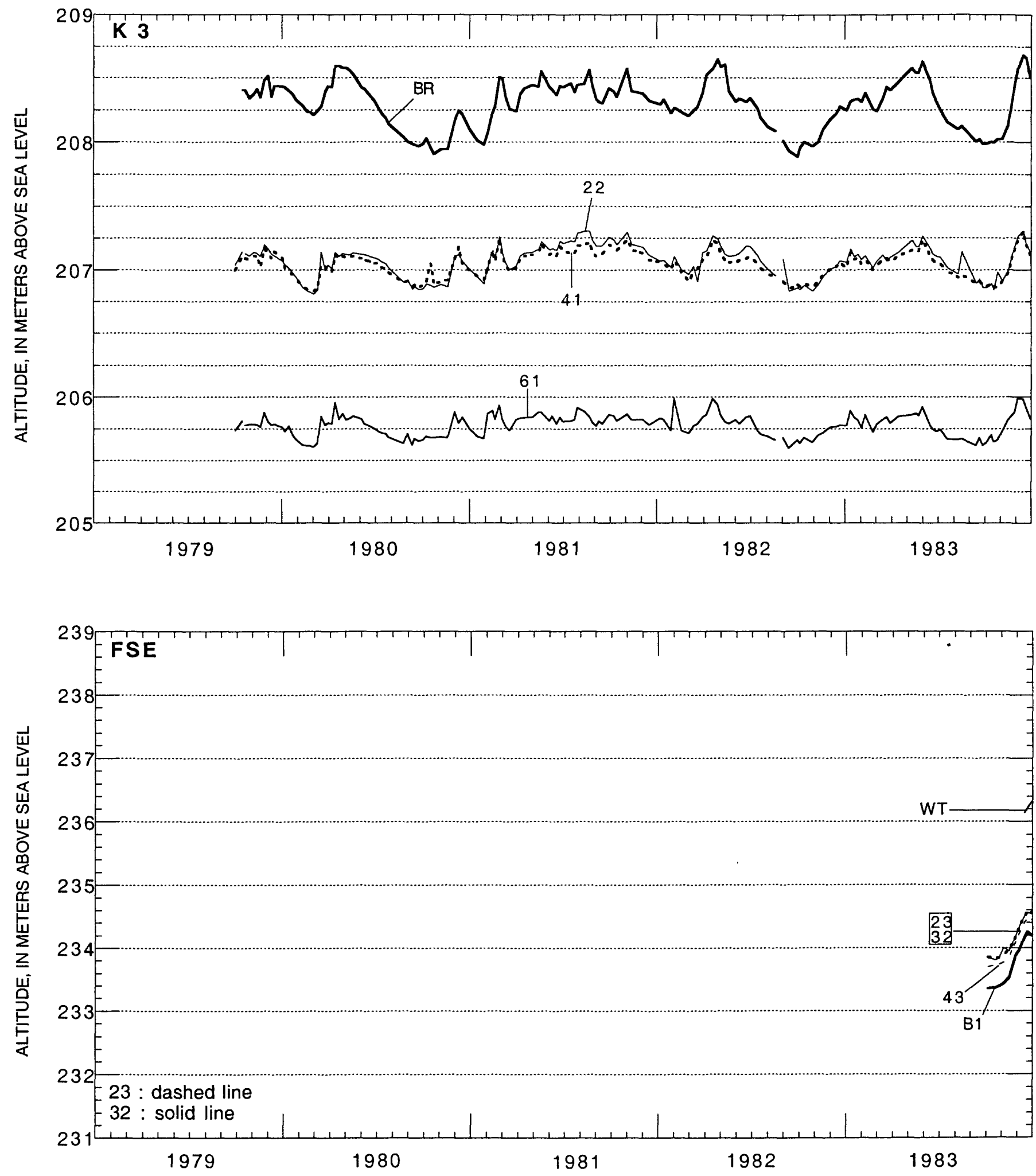

Figure 13. Hydraulic head within the ground-water system at piezometer nests K3 and FSE. Hydrograph labels indicate the depth of the bottom of the well screen in feet below land surface. Head of the the water table at piezometer nest FSE is indicated by the hydrograph labeled WT. Head in bedrock is indicated by the hydrograph labeled BR for K3 and B1 for FSE 

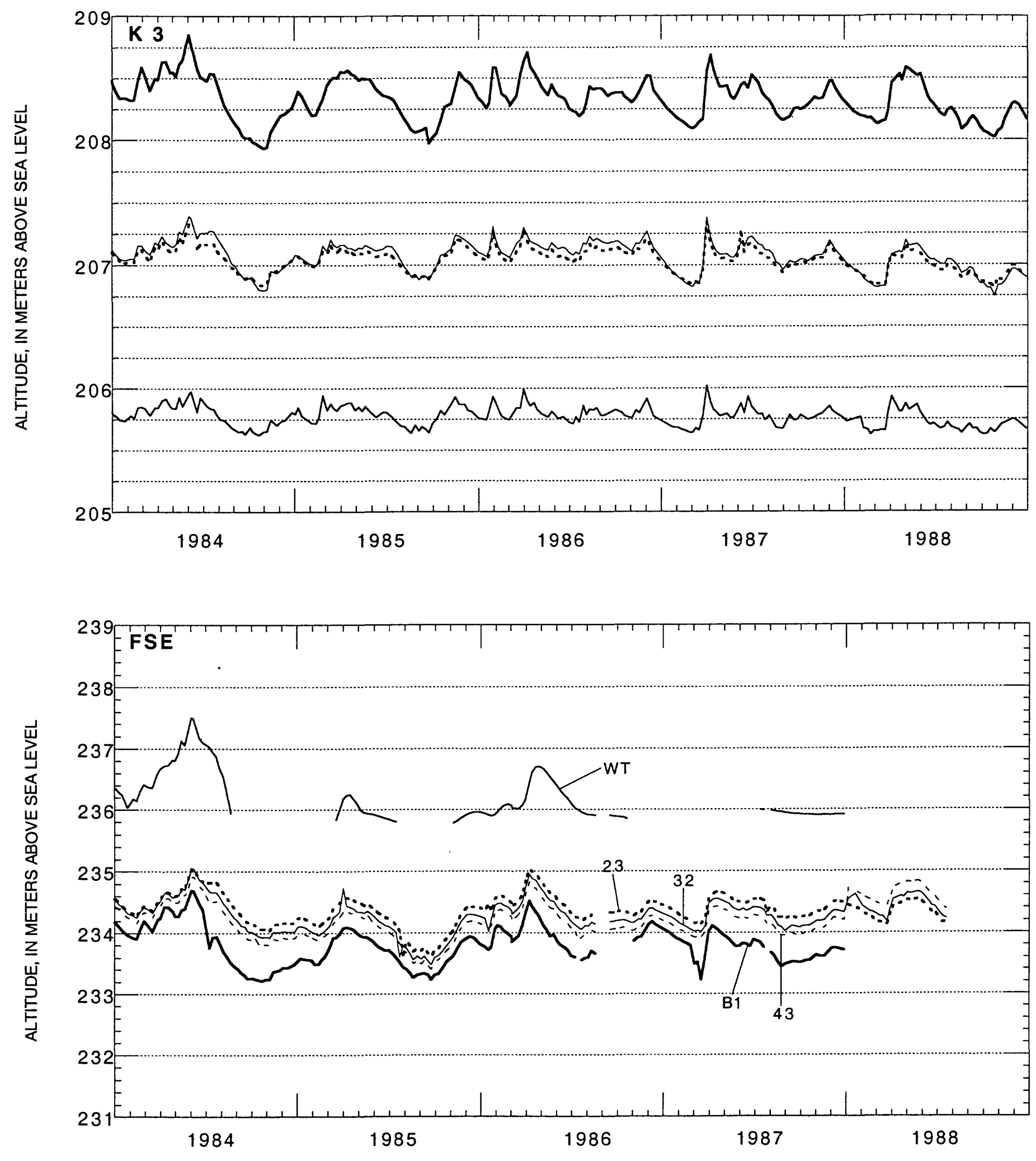


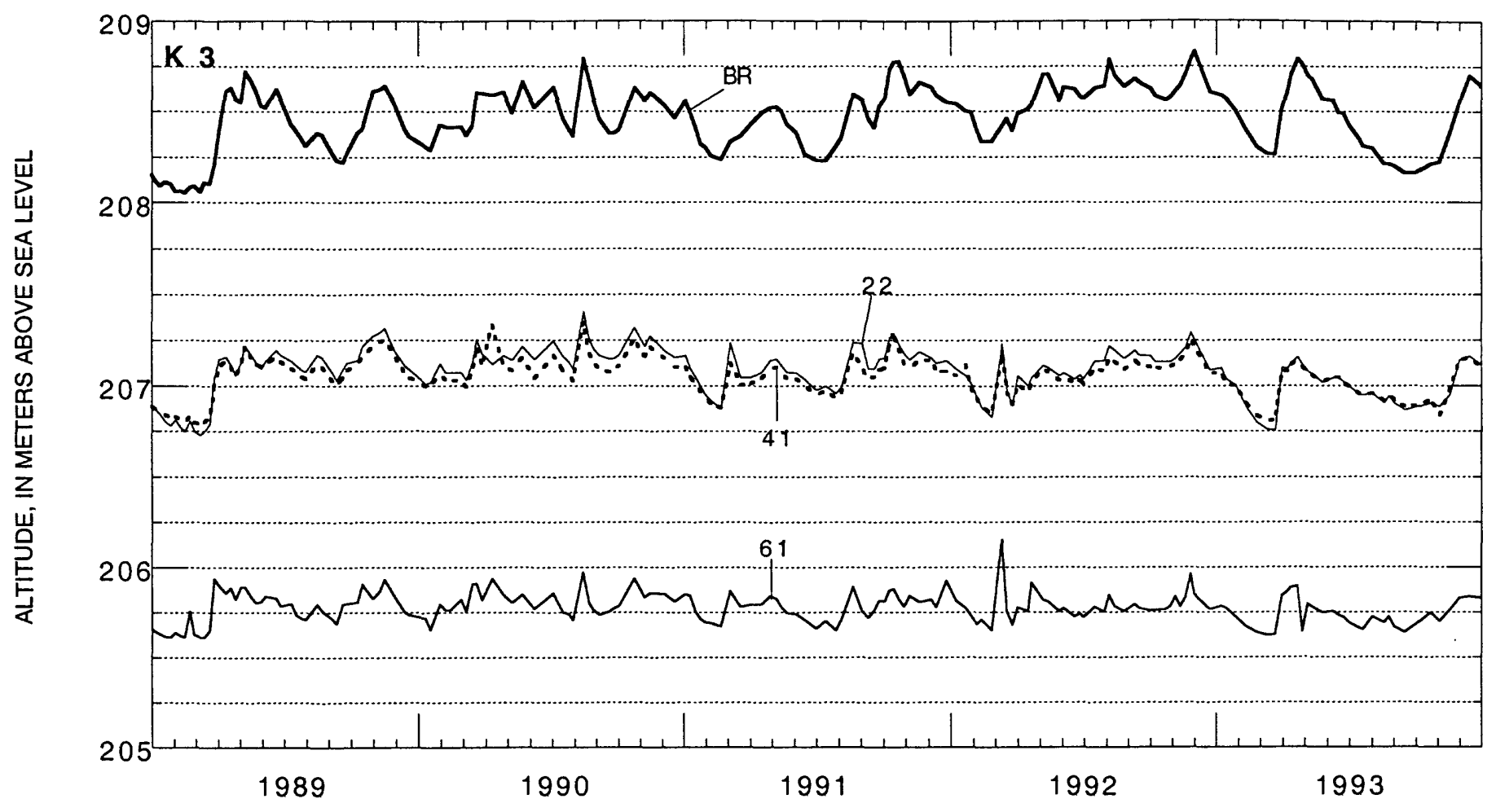

Figure 13. Hydraulic head within the ground-water system at piezometer nests K3 and FSE. - Continued 


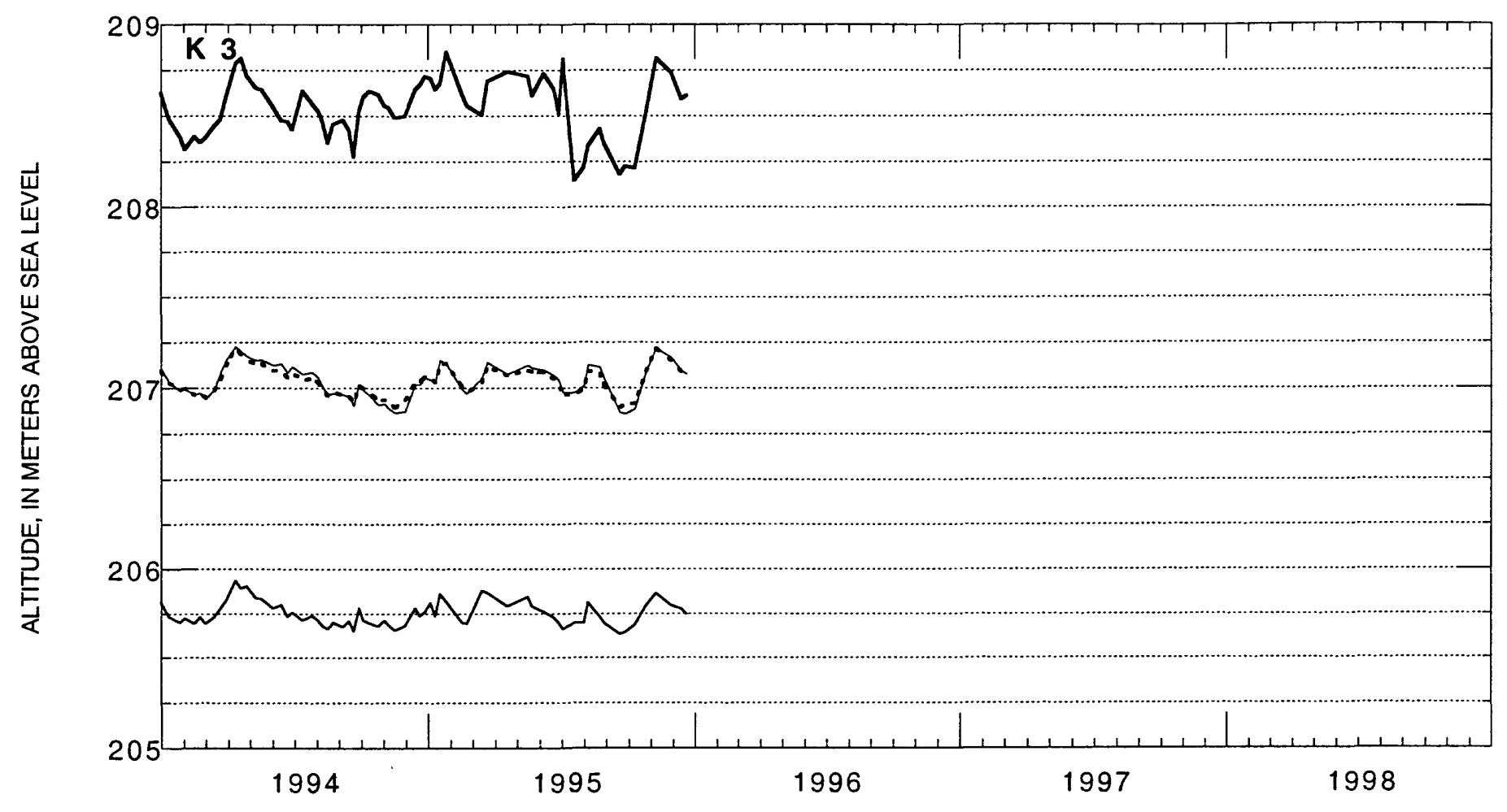



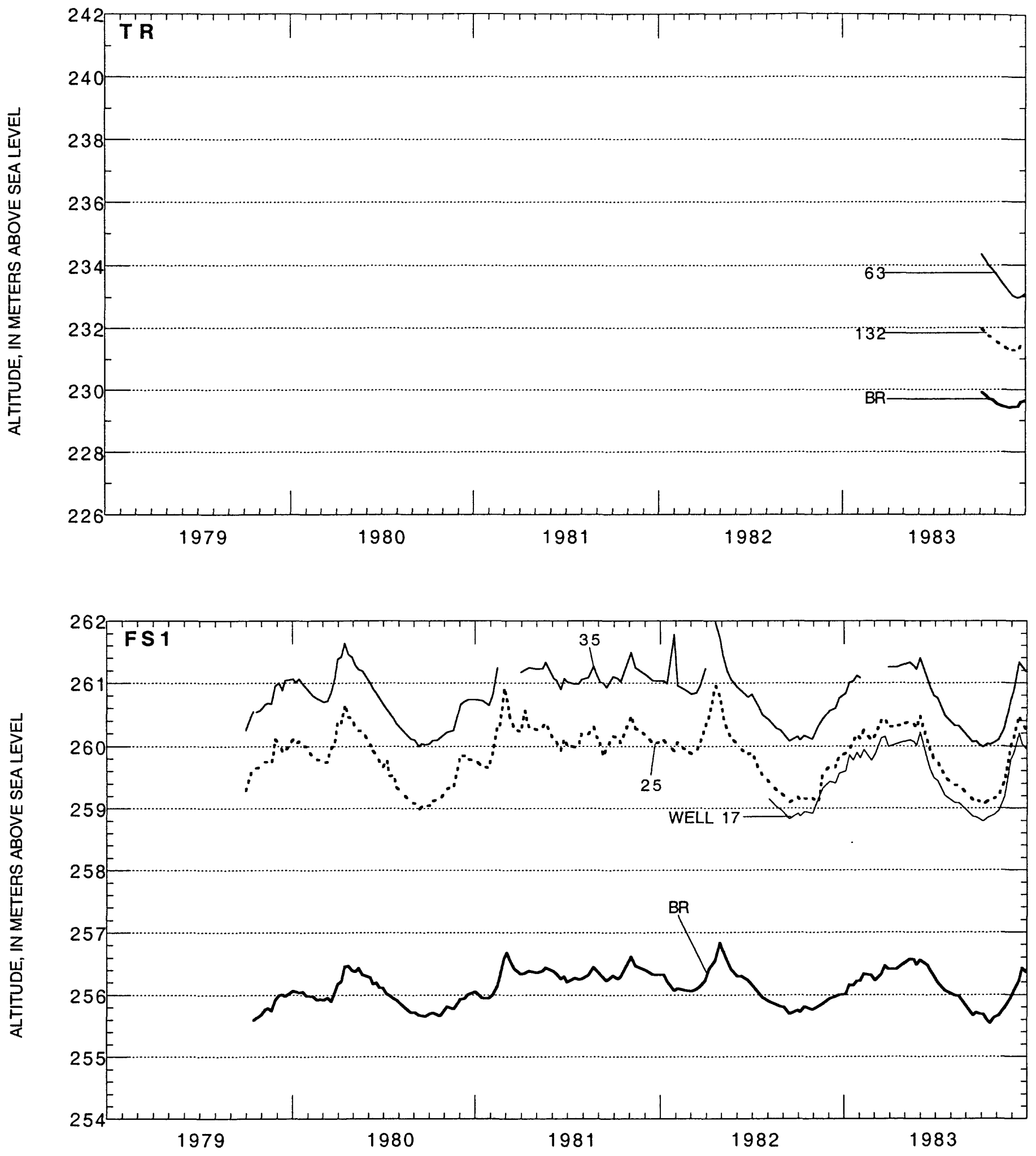

Figure 14. Hydraulic head within the ground-water system at piezometer nests TR and FS1. Hydrograph labels indicate the depth of the bottom of the well screen in feet below land surface. Well 17 is a water-table well at piezometer nest FS1. Head in bedrock is indicated by the hydrograph labeled BR. 

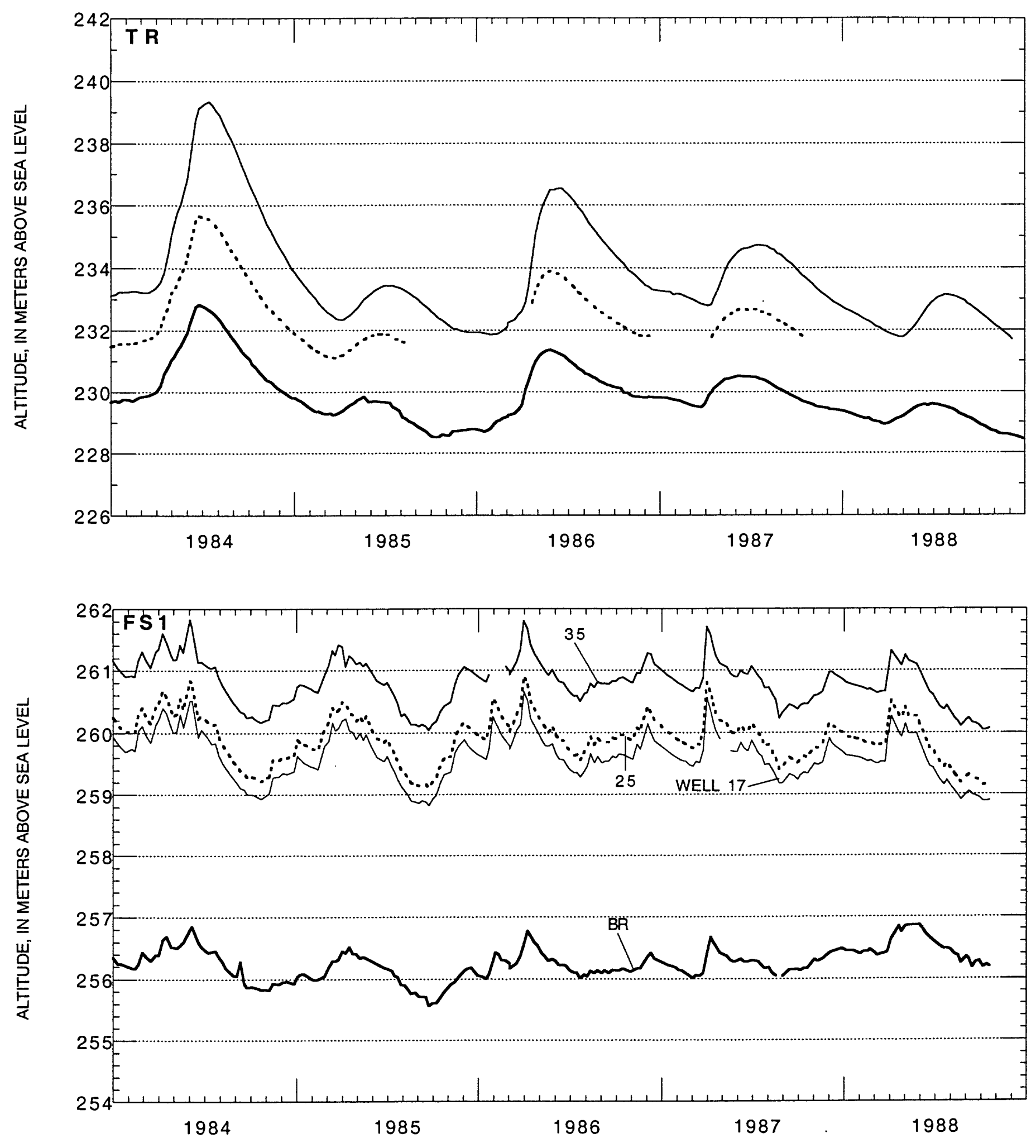


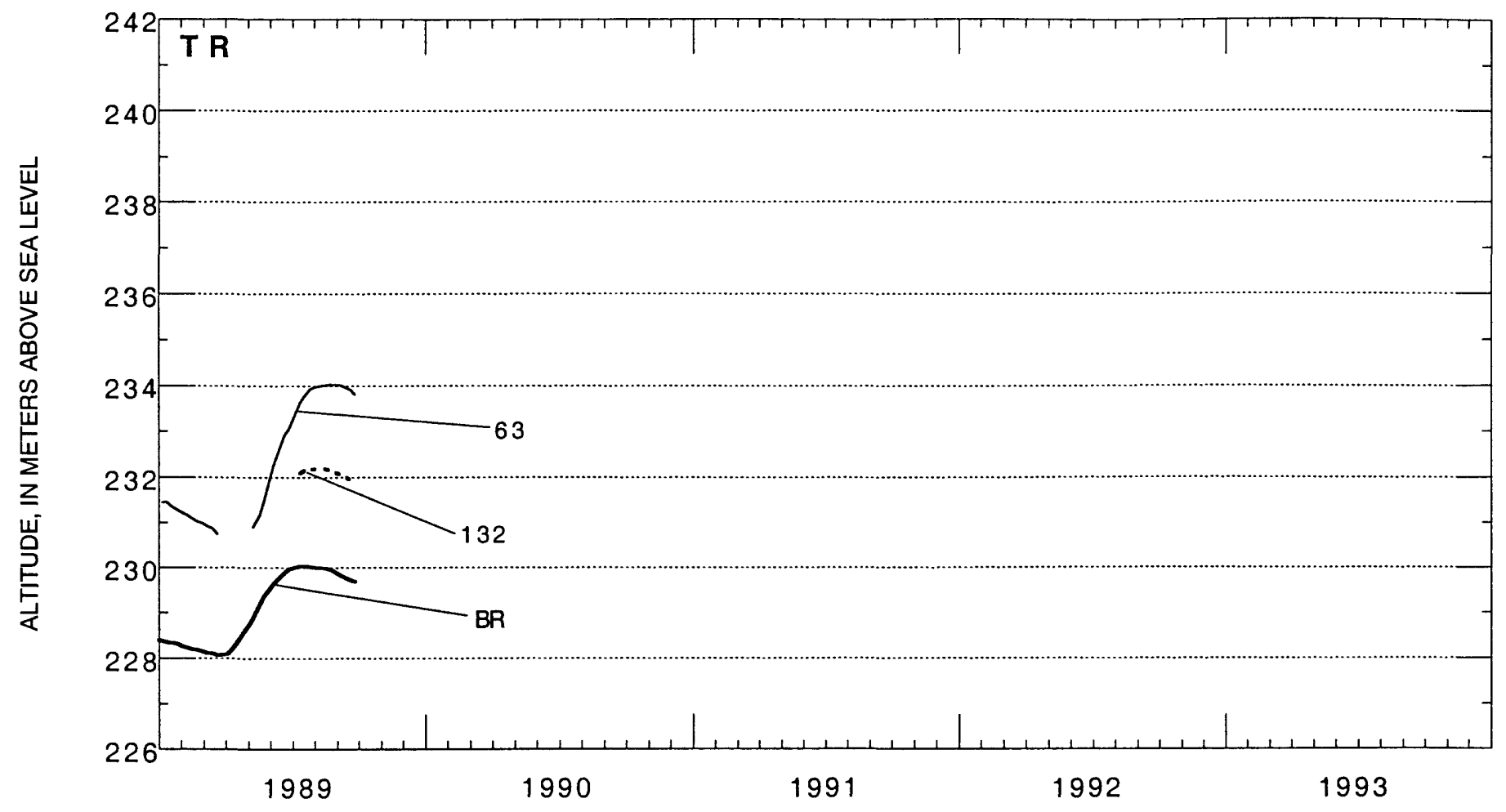

Figure 14. Hydraulic head within the ground-water system at piezometer nests TR and FS1. - Continued 